\title{
The Cell-surface Heparan Sulfate Proteoglycan Glypican-1 Regulates Growth Factor Action in Pancreatic Carcinoma Cells and Is Overexpressed in Human Pancreatic Cancer
}

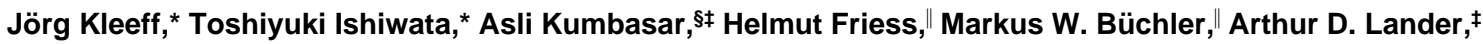 \\ and Murray Korc* \\ *Departments of Medicine, Biological Chemistry, and Pharmacology, and ${ }^{\ddagger}$ Department of Developmental and Cell Biology and \\ Developmental Biology Center, University of California, Irvine, California 92697; ${ }^{\S}$ Department of Biology, Massachusetts Institute of \\ Technology, Cambridge, Massachusetts 02139; and ${ }^{\|}$Department of Visceral and Transplantation Surgery, University of Bern, 3010 Bern, \\ Switzerland
}

\begin{abstract}
Heparan sulfate proteoglycans (HSPGs) play diverse roles in cell recognition, growth, and adhesion. In vitro studies suggest that cell-surface HSPGs act as coreceptors for heparin-binding mitogenic growth factors. Here we show that the glycosylphosphatidylinositol- (GPI-) anchored HSPG glypican-1 is strongly expressed in human pancreatic cancer, both by the cancer cells and the adjacent fibroblasts, whereas expression of glypican-1 is low in the normal pancreas and in chronic pancreatitis. Treatment of two pancreatic cancer cell lines, which express glypican-1, with the enzyme phosphoinositide-specific phospholipase-C (PI-PLC) abrogated their mitogenic responses to two heparin-binding growth factors that are commonly overexpressed in pancreatic cancer: fibroblast growth factor 2 (FGF2) and heparinbinding EGF-like growth factor (HB-EGF). PI-PLC did not alter the response to the non-heparin-binding growth factors EGF and IGF-1. Stable expression of a form of glypican-1 engineered to possess a transmembrane domain instead of a GPI anchor conferred resistance to the inhibitory effects of PI-PLC on growth factor responsiveness. Furthermore, transfection of a glypican-1 antisense construct attenuated glypican-1 protein levels and the mitogenic response to FGF2 and HB-EGF. We propose that glypican-1 plays an essential role in the responses of pancreatic cancer cells to certain mitogenic stimuli, that it is relatively unique in relation to other HSPGs, and that its expression by pancreatic cancer cells may be of importance in the pathobiology of this disorder. (J. Clin. Invest. 1998. 102:1662-1673.) Key words: glypican-1 pancreas $\cdot$ cancer $\cdot$ growth factors $\cdot$ heparin binding
\end{abstract}

\section{Introduction}

Membrane-associated heparan sulfate proteoglycans (HSPGs) ${ }^{1}$ are thought to play important roles in many aspects of cell be-

Address correspondence to Murray Korc, Division of Endocrinology, Diabetes and Metabolism, Medical Sciences I, C240, University of California, Irvine, CA. Phone: 949-824-6887; FAX: 949-824-1035; E-mail: mkorc@uci.edu

Received for publication 26 May 1998 and accepted in revised form 11 September 1998.

J. Clin. Invest.

(C) The American Society for Clinical Investigation, Inc. 0021-9738/98/11/1662/12 \$2.00

Volume 102, Number 9, November 1998, 1662-1673

http://www.jci.org havior, including cell-cell and cell-extracellular matrix adhesion $(1,2)$ and growth factor signaling $(3,4)$. Two families of polypeptides appear to carry the majority of the heparan sulfate on mammalian cells: glypicans, which are attached to the plasma membrane via glycosylphosphatidylinositol (GPI) anchors, and syndecans, which are transmembrane proteins (3, $5)$. Four syndecans and five glypicans, all encoded by separate genes, have been described to date (5-10). Many of these polypeptides exhibit tissue-specific patterns of expression, although these patterns often overlap (11-14). In vitro, at least, it is common for cells to express multiple HSPGs, often from both the glypican and syndecan families.

The role of HSPGs in growth factor signaling has been best characterized with respect to fibroblast growth factors (FGFs), which require the presence of heparan sulfate for high affinity binding to their tyrosine kinase receptors (15-17). More recently, several other growth factors have been found to exhibit a strong requirement for an HSPG coreceptor in their signaling; these include heparin-binding EGF-like growth factor (HB-EGF), hepatocyte growth factor (HGF), and members of the Wnt family of secreted glycoproteins (18-21). Many other growth factors, including vascular endothelial growth factor (VEGF), PDGF, TGF- $\beta$ s, and bone morphogenetic proteins (BMPs), are known to bind heparin and heparan sulfate, although the physiological consequences of this binding are unclear.

Pancreatic cancer is responsible for over $20 \%$ of deaths due to gastrointestinal malignancies, making it the fourth to fifth most common cause of cancer-related mortality. The prognosis of patients with pancreatic cancer is extremely poor, with 5 -yr survival rates lower than 5\% (22). The reasons for this biological aggressiveness have not been clearly elucidated. Nonetheless, previous work has established that these cancers overexpress many mitogenic growth factors and their receptors (23) including a number of heparin-binding growth factors such as FGF1, FGF2, FGF5, HB-EGF, and amphiregulin (24-27). To date, the role of HSPGs in the proliferative responses of pancreatic cancer cells has not been studied. Here we report two findings that bear on this question. First, we show that glypican-1 expression, both mRNA and protein, is dramatically upregulated in human pancreatic cancers. Second, we show that glypican-1 is highly expressed by human pancreatic carcinoma cell lines in vitro, and that in such cells

1. Abbreviations used in this paper: EGF, epidermal growth factor; FGF, fibroblast growth factor; GPI, glycosylphosphatidylinositol; HB-EGF, heparin-binding EGF-like growth factor; HSPG, heparan sulfate proteoglycan; nt, nucleotides; PI-PLC, phosphoinositide-specific phospholipase C; VSVG, vesicular stomatitis virus glycoprotein. 
glypicans (and no other classes of HSPGs) are uniquely required for FGF2- and HB-EGF-induced mitogenesis. Together, these results suggest that glypican-1 may play a crucial role in the growth factor signaling pathways underlying an aggressive human cancer.

\section{Methods}

Materials. The following materials were purchased: FBS, DMEM, and RPMI medium, trypsin solution, penicillin-streptomycin solution, and Geneticin (G418) from Irvine Scientific (Santa Ana, CA); Genescreen membranes from New England Nuclear (Boston, MA); restriction enzymes, $\mathrm{pMH}$ vector, the random primed labeling kit, the Genius 3 nonradioactive nucleic acid detection kit, and the Genius 4 RNA labeling kit from Boehringer-Mannheim (Indianapolis, IN); phosphoinositide-specific phospholipase-C (PI-PLC) from Oxford Glycosciences Inc. (Bedford, MA); Sequenase version 1.0 DNA Sequencing from USB Specialty Biochemicals (Cleveland, OH); $[\alpha-$ $\left.{ }^{32} \mathrm{P}\right] \mathrm{dCTP},\left[\alpha-{ }^{32} \mathrm{P}\right] \mathrm{CTP}$, and $\left[\gamma^{-35} \mathrm{~S}\right] \mathrm{dATP}$ from Amersham (Arlington Heights, IL); DNA molecular weight markers and Lipofectamine from GIBCO BRL (Gaithersburg, MD); anti-c-myc (9E10), antiERK-1, and horseradish peroxidase-conjugated anti-rabbit antibodies from Santa Cruz Biotechnology, Inc. (Santa Cruz, CA); Cy3-conjugated anti-rabbit IgG antibodies from Jackson ImmunoResearch (West Grove, PA); pBluescript-IISK + from Stratagene (La Jolla, CA); DEAE-Sephacel from Pharmacia Biotech (Piscataway, NJ); enhanced chemiluminescence (ECL) blotting kit from Pierce (Rockford, IL); pCDNA3.1 Myc-His from Invitrogen (Carlsbad, CA); Centriprep Concentrators from Amicon Inc. (Beverly, MA); Lab-Tek Chamber Slides from Nunc Inc. (Naperville, IL); adult and fetal human multiple tissue Northern blots from Clontech (Palo Alto, CA); Heparitinase (Heparinase III) and all other reagents from Sigma Chemical Co. (St. Louis, MO). PANC-1, MIA-PaCa-2, ASPC-1, CAPAN-1 human pancreatic cell lines were obtained from American Type Culture Collection (Rockville, MD). COLO-357 and T3M4 human pancreatic cell lines were a gift from Dr. R.S. Metzger (Duke University, Durham, NC).

Tissue samples. Normal human pancreatic tissue samples (7 male, 5 female donors; median age: $41.8 \mathrm{yr}$; range: $14-68 \mathrm{yr}$ ), chronic pancreatitis tissues (13 male donors, 1 female donor; median age: 42.1 yr; range: 30-56 yr), and pancreatic cancer tissues (10 male, 6 female donors; median age: $62.6 \mathrm{yr}$; range: $53-83 \mathrm{yr}$ ) were obtained through an organ donor program and from surgical specimens obtained from patients with severe symptomatic chronic pancreatitis or from pancreatic cancer patients. According to the TNM classification of the Union Internationale Contre le Cancer (UICC), six tumors were stage 1 , one was stage 2 , and nine were stage 3 ductal cell adenocarcinoma. Freshly removed tissue samples were fixed in $10 \%$ formaldehyde solution for 12-24 $\mathrm{h}$ and paraffin embedded for histological analysis. In addition, tissue samples were frozen in liquid nitrogen immediately upon surgical removal and maintained in $-80^{\circ} \mathrm{C}$ until used for RNA extraction. All studies were approved by the Ethics Committee of the University of Bern and by the Human Subjects Committee at the University of California, Irvine.

Construction of vectors. A 599-bp human glypican cDNA probe (nucleotides [nt] 920-1518) was isolated as described previously (28) and subcloned into Bluescript-IISK + vector. For in situ hybridization, a 210-bp cDNA fragment (nt 1280-1489) of human glypican was subcloned into Bluescript-IISK + vector. Authenticity was confirmed by sequencing. Glypican-2 and -5 constructs were prepared as described previously $(7,10)$. A 239-bp human glypican-3 cDNA fragment, corresponding to nt $927-1165$ of the human glypican-3 cDNA sequence (EMBL/Genbank/DDBJ HSU50410), and a 273-bp human glypican-4 cDNA fragment, corresponding to nt 12-284 of a human glypican-4 EST sequence (EMBL/Genbank/DDBJ AA046130) were generated by reverse transcription PCR from human placenta RNA. The primers used for the glypican-3/-4 preparation contained an
EcoRI and BamHI site, respectively, attached to the $5^{\prime}$ end and preceded by a 3-bp overhang. Glypican-3 sense: 5'-AGT-GGATCCCTGCTCTTACTGCCAGGGAC; antisense: 5'-GTA-GAATTC-GCTTTCCTGCATTCTTCTGG. Glypican-4 sense: 5'-AGT-GGATCCGTTGACACCAGCAAACCAGA; antisense: 5'-GTA-GAATTCAGTGAGGAGGTAGGCCTGTG. Authenticity was confirmed by sequencing. An eukaryotic expression vector that directs expression of a transmembrane version of glypican- 1 was constructed by fusing the membrane domain of the vesicular stomatitis virus glycoprotein (VSVG; reference 29) with the extracellular domain of glypican-1. In brief, an 80-bp fragment encoding the transmembrane domain of VSVG (VSVGTMR) was amplified using the primers sense: $5^{\prime}$-GCCACGTGTCCATTGCCTCTTTTTC and antisense: 5'-GCTCTAGACTAAAGCTTGAGAACCAA, digested with EcoRI and XbaI, and subcloned into the pCDNA3.1-Myc-His expression vector. Next, a BamHI-PmlI $1.7 \mathrm{~kb}$ fragment, corresponding to the extracellular domain of the rat glypican-1 was inserted into the pCDNA3.1 mycHis (VSVGTMR) expression vector by directional cloning. The construct was termed glyp1-VSVGTMR. Authenticity was confirmed by sequencing. The final result contained amino acids 1-539 of rat glypican-1 followed by HVSIASFFFIIGLIIGLFVVLKLSRGPFEQKLISEEDLNMHTGHHHHHH. A glypican-1 antisense construct was prepared by PCR amplification of human placenta cDNA. The 1751bp fragment (nt 123-1873), which covered from 100 bp downstream of the start codon to $25 \mathrm{bp}$ downstream of the end of the coding region, was subcloned in the antisense orientation into the pMH expression vector. The primers used for the glypican- 1 preparation contained a EcoRI and HindIII site, respectively, attached to the $5^{\prime}$ end and preceded by a 3 bp overhang. Sense: 5'-GTA-GAATTC-GGACCTTGGCTCTGCCCTTC, antisense: 5'-AGT-AAGCTT-GTAAGGGCCAGGAAGAGGAG. The construct was termed G1-AS-1751. Authenticity was confirmed by sequencing.

RNA extraction and Northern blot analysis. Total RNA was extracted by the single step-acid guanidinium thiocyanate phenol chloroform method. RNA was size fractionated on $1.2 \%$ agarose $/ 1.8 \mathrm{M}$ formaldehyde gels, electrotransferred onto nylon membranes, and cross-linked by UV irradiation. Blots were prehybridized and hybridized with cDNA probes or riboprobes and washed under high stringency conditions as previously reported (30). Blots were then exposed at $-80^{\circ} \mathrm{C}$ to XAR-5 films (Eastman Kodak, Rochester, NY) and the resulting autoradiographs were scanned to quantify the intensity of the radiographic bands. A BamHI 190-bp fragment of mouse $7 \mathrm{~S}$ cDNA that hybridizes with human cytoplasmatic RNA was used to confirm equal RNA loading and transfer (30).

Immunohistochemistry. An affinity-purified rabbit anti-rat glypican-1 antibody (12) that also recognizes human glypican-1 was used for immunohistochemistry. Paraffin-embedded sections $(4 \mu \mathrm{m})$ from pancreatic cancer, chronic pancreatitis, and normal pancreatic tissues were subjected to immunostaining using the streptavidin-peroxidase technique. Endogenous peroxidase activity was blocked by incubation for 30 min with $0.3 \%$ hydrogen peroxide in methanol. Tissue sections were incubated for $15 \mathrm{~min}$ (room temperature) with $10 \%$ normal goat serum and then incubated for $16 \mathrm{~h}$ at $4^{\circ} \mathrm{C}$ with glypican antibody $(2.5 \mu \mathrm{g} / \mathrm{ml})$ in PBS containing $1 \%$ BSA. Bound antibodies were detected with biotinylated goat anti-rabbit IgG secondary antibodies and streptavidin-peroxidase complex, using diaminobenzidine tetrahydrochloride as the substrate. Sections were counterstained with Mayer's hematoxylin. Sections incubated with nonimmune rabbit IgG or without primary antibodies did not yield positive immunoreactivity. Furthermore, preabsorption of the anti-glypican- 1 antibody with the glypican-1 peptide to which the antibody had been raised completely abolished immunoreactivity.

Immunoblotting. Cells were washed with $\mathrm{PBS}\left(4^{\circ} \mathrm{C}\right)$ and solubilized in lysis buffer containing $50 \mathrm{mM}$ Tris- $\mathrm{HCl}, \mathrm{pH} 7.4,150 \mathrm{mM}$ $\mathrm{NaCl}, 1 \mathrm{mM}$ EDTA, $1 \mu \mathrm{g} / \mathrm{ml}$ pepstatin A, $1 \mathrm{mM}$ PMSF, and $1 \%$ Triton X-100. Digestion with heparitinase $(1 \mathrm{U} / \mathrm{ml})$ was performed in a volume of $30 \mu \mathrm{l}$ at $37^{\circ} \mathrm{C}$ for $6 \mathrm{~h}$ and terminated by the addition of 7.5 $\mu l 5 \times$ SDS sample buffer and heating at $95^{\circ} \mathrm{C}$ for $10 \mathrm{~min}$. For prepa- 
ration of membranes, cells or tissue samples were homogenized in 20 mM Hepes, $\mathrm{pH} 7.4,1.5 \mathrm{mM} \mathrm{MgCl}_{2}, 1$ mM EGTA, 1 mM PMSF, $2 \mathrm{mM}$ benzamidine, and centrifuged at $1,500 \mathrm{~g}$ for $10 \mathrm{~min}$. Supernatants were collected and centrifuged at 25,000 $\mathrm{g}$ for $30 \mathrm{~min}$. Pellets were resuspended in $20 \mathrm{mM}$ Hepes, pH 7.4, containing $10 \mathrm{mM}$ leupeptin. For reduction and alkylation with iodoacetamide, protein lysates were incubated at $95^{\circ} \mathrm{C}$ for $4 \mathrm{~min}$ in the presence of $10 \mathrm{mM}$ DTT. Subsequently, iodoacetamide was added to the samples to a final concentration of $50 \mathrm{mM}$ and incubated at $95^{\circ} \mathrm{C}$ for $2 \mathrm{~min}$. Proteins were subjected to SDS-PAGE and transferred to Immobilon $\mathrm{P}$ membranes. Membranes were incubated for $90 \mathrm{~min}$ with a polyclonal rabbit anti-rat glypican-1 (250 ng/ml) antibody, washed, and incubated with a secondary antibody against rabbit $\mathrm{IgG}$ for $60 \mathrm{~min}$. After washing, visualization was performed by ECL.

Glypican-1 purification. Glycanated glypican-1 was purified by anion exchange chromatography on DEAE-Sephacel equilibrated in buffer A (50 mM Tris-HCl, pH 8.0, 0.15 M NaCl, $0.1 \%$ Triton X-100). Cell lysates in buffer B (50 mM Tris-HCl, pH 8.0, $0.15 \mathrm{M} \mathrm{NaCl}, 0.1 \%$ Triton X-100, $1 \mathrm{mM}$ EDTA, $1 \mu \mathrm{g} / \mathrm{ml}$ pepstatin A, $1 \mathrm{mM}$ PMSF) were loaded directly onto columns containing the gel. Column volumes of $0.5 \mathrm{ml}$ of packed gel per milligram protein were used. Columns were eluted stepwise with buffer A, buffer C (50 mM Tris-HCl, $\mathrm{pH} 8.0$, $0.25 \mathrm{M} \mathrm{NaCl}, 0.1 \%$ Triton X-100), buffer D (50 mM Tris-HCl, $\mathrm{pH} 8.0$, $6 \mathrm{M}$ urea, $0.25 \mathrm{M} \mathrm{NaCl}, 0.1 \%$ Triton X-100), and buffer E (50 mM sodium formate, $\mathrm{pH} 3.5,6 \mathrm{M}$ urea, $0.2 \mathrm{M} \mathrm{NaCl}, 0.1 \%$ Triton $\mathrm{X}-100)$. Column $\mathrm{pH}$ was restored with $50 \mathrm{mM}$ Tris- $\mathrm{HCl}, \mathrm{pH} 8.0,0.1 \%$ Triton $\mathrm{X}-100$ before elution of glypican-1 with buffer $\mathrm{F}(50 \mathrm{mM}$ Tris- $\mathrm{HCl}$, $\mathrm{pH}$ 8.0, $0.75 \mathrm{M} \mathrm{NaCl}, 0.1 \%$ Triton X-100). Eluted material was diluted fivefold with $50 \mathrm{mM}$ Tris, $\mathrm{pH} 8.0,0.1 \%$ Triton X-100, and concentrated and clarified by 10,000 mol wt cutoff YM membrane filtration. Samples were resuspended in buffer B and analyzed by immunoblotting.

In situ hybridization. To carry out in situ hybridization, tissue sections (4- $\mu \mathrm{m}$ thick) were placed on 3-aminopropyl-methoxysilanecoated slides, deparaffinized, and incubated at room temperature for 20 min with $0.2 \mathrm{~N} \mathrm{HCl}$ and for $15 \mathrm{~min}$ with $20 \mu \mathrm{g} / \mathrm{ml}$ proteinase $\mathrm{K}$ at $37^{\circ} \mathrm{C}$. The sections were then postfixed for $5 \mathrm{~min}$ in PBS containing $4 \%$ paraformaldehyde and incubated briefly twice with PBS containing $2 \mathrm{mg} / \mathrm{ml}$ glycine and once in $50 \%$ (vol/ $/ \mathrm{vol}$ ) formamide $/ 2 \times \mathrm{SSC}$ for $1 \mathrm{~h}$ before initiation of the hybridization reaction by the addition of $100 \mu \mathrm{l}$ of hybridization buffer. The hybridization buffer contained $0.6 \mathrm{M}$ $\mathrm{NaCl}, 1 \mathrm{mM}$ EDTA, $10 \mathrm{mM}$ Tris- $\mathrm{HCl}$ (pH 7.5), 0.25\% SDS, $200 \mu \mathrm{g} / \mathrm{ml}$ yeast tRNA, $1 \times$ Denhardt's solution, $10 \%$ dextran sulfate, $40 \%$ formamide, and $100 \mathrm{ng} / \mathrm{ml}$ of the indicated digoxigenin-labeled riboprobe. Hybridization was performed in a moist chamber for $16 \mathrm{~h}$ at $42^{\circ} \mathrm{C}$. The sections were then washed sequentially with $50 \%$ formamide $/ 2 \times$ SSC for $30 \mathrm{~min}$ at $42^{\circ} \mathrm{C}, 2 \times \mathrm{SSC}$ for $20 \mathrm{~min}$ at $42^{\circ} \mathrm{C}$, and $0.2 \times \mathrm{SSC}$ for $20 \mathrm{~min}$ at $42^{\circ} \mathrm{C}$. For immunological detection, the Genius 3 nonradioactive nucleic acid detection kit was used. The sections were washed briefly with buffer 1 solution $(100 \mathrm{mM}$ Tris- $\mathrm{HCl}$ and $150 \mathrm{mM} \mathrm{NaCl}$, $\mathrm{pH} 7.5)$ and incubated with $1 \%(\mathrm{wt} / \mathrm{vol})$ blocking reagents in buffer 1 solution for $60 \mathrm{~min}$ at room temperature. The sections were then incubated for $30 \mathrm{~min}$ at room temperature with a 1:2,000 dilution of alkaline phosphatase-conjugated polyclonal sheep antidigoxigenin Fab fragment antibody, washed twice for $15 \mathrm{~min}$ at room temperature with buffer 1 solution containing $0.2 \%$ Tween 20 , and equilibrated for 2 min with buffer 2 solution $(100 \mathrm{mM}$ Tris- $\mathrm{HCl}, 100 \mathrm{mM} \mathrm{NaCl}, 50$ $\mathrm{mM} \mathrm{MgCl}$, $\mathrm{pH}$ 9.5). The sections were then incubated with color solution containing nitroblue tetrazolium and $\mathrm{X}$-phosphate in a dark box for 2-3 h. After the reaction was stopped with TE buffer $(10 \mathrm{mM}$ Tris-HCl, pH 7.4, 1 mM EDTA, pH 8.0), the sections were mounted in aqueous mounting medium.

Cell culture and growth assay. Human pancreatic cancer cells were routinely grown in DMEM (COLO-357, MIA-PaCa-2, PANC-1) or RPMI (ASPC-1, CAPAN-1, T3M4) supplemented with 10\% FBS, $100 \mathrm{U} / \mathrm{ml}$ penicillin, and $100 \mu \mathrm{g} / \mathrm{ml}$ streptomycin (complete medium). To perform growth assays, COLO-357 and PANC- 1 cells were plated overnight at a density of 10,000 cells/well in 96-well plates, washed in
HBSS, and subsequently incubated in serum-free medium (DMEM containing $0.1 \%$ BSA, $5 \mu \mathrm{g} / \mathrm{ml}$ transferrin, $5 \mathrm{ng} / \mathrm{ml}$ sodium selenite, and antibiotics) in the absence or presence of various growth factors. For experiments with PI-PLC, cells were incubated with the indicated concentrations of PI-PLC for $1 \mathrm{~h}$. Subsequently, the medium was removed and serum-free medium supplemented with PI-PLC and growth factors were added. Incubations were continued for the indicated time before adding 3-(4,5-methylthiazol-2-yl)-2,5-diphenyl-tetrazolium bromide (MTT; $62.5 \mu \mathrm{g} / \mathrm{well}$ ) for $4 \mathrm{~h}$ (31). Cellular MTT was solubilized with acidic isopropanol and optical density was measured at $570 \mathrm{~nm}$ with an ELISA plate reader (Molecular Devices, Menlo Park, CA). In pancreatic cancer cells, the results of the MTT assay correlate with results obtained by cell counting with a hemocytometer and by monitoring $\left[{ }^{3} \mathrm{H}\right]$ thymidine incorporation $(31,32)$.

Transient and stable transfections. Transient transfection of the glypican-1 antisense construct pMH6/G1-AS-1750 was carried out by the lipofectamine method. $24 \mathrm{~h}$ after transfection, cells were plated in 96-well plates for growth assays as described earlier. Stable transfection of pCDNA3.1/glyp1-VSVGTMR into PANC-1 cells was also performed using the lipofectamine method. After reaching confluence, cells were split 1:10 into selection medium (complete medium supplemented with $1 \mathrm{mg} / \mathrm{ml} \mathrm{G} 418$ ) and single clones were isolated after 2-4 wk. After expansion, cells from each individual clone were screened for expression of glypican-1 by Northern and Western blot analysis. Parental PANC-1 cells were also transfected with an empty expression vector carrying the neomycin-resistance gene as a control. Positive clones were routinely grown in selection medium.

Immunofluorescence. Cells were plated at a density of 100,000 cells/slide on culture chamber slides and incubated for $24 \mathrm{~h}$ in complete medium. Subsequently, cells were incubated for $1 \mathrm{~h}$ in serumfree medium in the absence or presence of PI-PLC $(0.5 \mathrm{U} / \mathrm{ml})$, washed, and incubated for $30 \mathrm{~min}$ at room temperature in DMEM containing $5 \%$ goat serum, $5 \%$ FBS, and $10 \mathrm{mM}$ Hepes, $\mathrm{pH} 7.5$. All antibody dilutions and washings were carried out at $4^{\circ} \mathrm{C}$ using this solution. Slides were then incubated for $60 \mathrm{~min}$ with the rabbit anti-rat glypican-1 antibody $(2.5 \mu \mathrm{g} / \mathrm{ml})$, washed, and incubated with a Cy3conjugated antibody against rabbit IgG for $60 \mathrm{~min}$. Cells were then washed, fixed, and prepared for immunofluorescence microscopy.

Statistics. Student's $t$ test was used for statistical analysis of the experiments. $P<0.05$ was taken as the level of significance. Results of MTT cell growth assays are expressed as SEM of at least three separate experiments.

\section{Results}

Glypican-1 expression in human pancreatic tissue. Northern blot analysis was performed on total RNA isolated from 12 normal pancreatic tissues, 16 pancreatic cancers, and 14 chronic pancreatitis samples. The $3.7-\mathrm{kb}$ glypican-1 mRNA transcript was of relatively low abundance, but clearly visible in 4 of 12 normal pancreatic tissue samples (Fig. $1 A$ ) and in 3 of 14 chronic pancreatitis samples. It was also faintly visible on the original autoradiographs in 7 normal and 9 chronic pancreatitis samples (Fig. $1 B$ ). In contrast, 12 of 16 pancreatic cancer samples exhibited moderate to high levels of glypican-1 mRNA (Fig. 1 $A)$. Densitometric analysis of all the autoradiograms indicated that by comparison with normal pancreatic tissues there was an eightfold increase $(P<0.01)$ in glypican-1 mRNA levels in the pancreatic cancer samples (Fig. 2). In contrast, glypican-1 mRNA levels were similar in chronic pancreatitis and normal pancreatic samples.

To determine whether glypican-1 protein levels were also elevated in pancreatic cancer, immunoblotting was carried out using a highly specific anti-glypican-1 antibody. Intact HSPGs, 


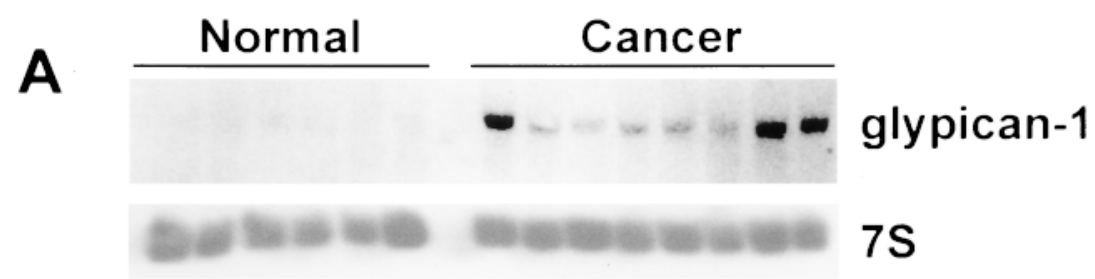

B

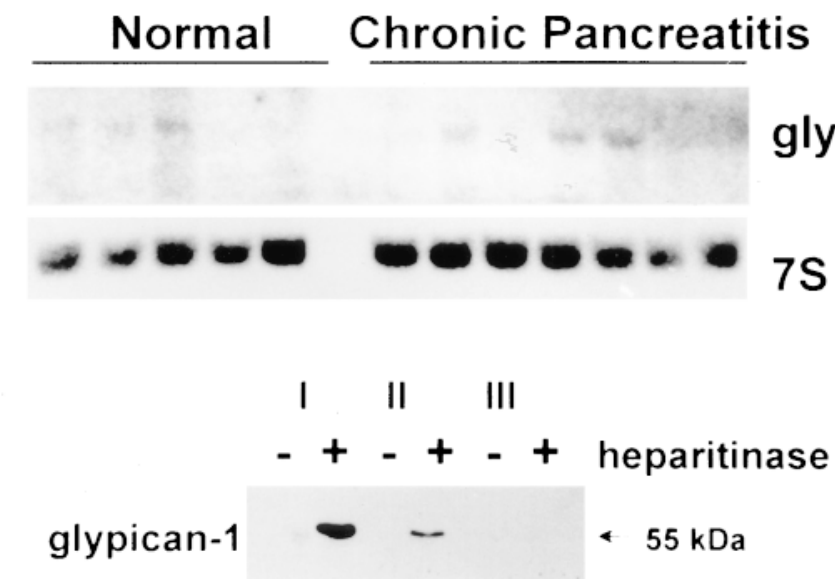

Figure 1. Expression of glypican-1 in pancreatic tissues. Total RNA (20 $\mu \mathrm{g} / \mathrm{lane})$ from six normal pancreatic tissues and eight pancreatic cancers $(A)$ and from five normal and seven chronic pancreatitis tissues $(B)$ were subjected to Northern blot analysis using a ${ }^{32} \mathrm{P}$-labeled glypican-1 cDNA probe $(500,000 \mathrm{cpm} / \mathrm{ml})$. A $7 \mathrm{~S}$ ribosomal cDNA probe $(50,000 \mathrm{cpm} / \mathrm{ml})$ was used as a loading and transfer control. Exposure times were $2 \mathrm{~d}$ for glypican-1 and $6 \mathrm{~h}$ for 7S. $(C)$ Glypican-1 protein expression in pancreatic cancers. Membrane preparations $(30 \mu \mathrm{g} / \mathrm{lane})$ from three pancreatic cancer tissue samples were incubated in the absence $(-)$ or presence $(+)$ of heparitinase for $6 \mathrm{~h}$ at $37^{\circ} \mathrm{C}$. Western blotting was carried out with an affinitypurified rabbit anti-rat glypican-1 antibody (250 $\mathrm{ng} / \mathrm{ml})$. including glypican-1, generally appear on immunoblots as broad high-mol wt smears having faint immunostaining, in part due to poor binding of proteoglycans to blotting membranes $(11,12,33)$. However, after digestion with heparitinase, HSPGs migrate as distinct bands on SDS-PAGE. Therefore, membrane preparations from normal and cancerous pancreatic tissue $(30 \mu \mathrm{g})$ were incubated in the absence or presence of heparitinase for $6 \mathrm{~h}$ at $37^{\circ} \mathrm{C}$ and subjected to SDS-PAGE followed by Western blot analysis. A single 55-kD band corre- sponding to the glypican-1 core protein was seen in four of six pancreatic cancer samples after heparitinase digestion, but not in untreated samples. In contrast, membrane preparations from four normal pancreatic tissues did not exhibit a glypican-1 band, even after heparitinase treatment. An example of an immunoblot experiment with pancreatic cancer tissues is shown in Fig. $1 C$.

Immunohistochemistry and in situ hybridization. To assess the exact sites of expression of glypican-1, immunohistochem-

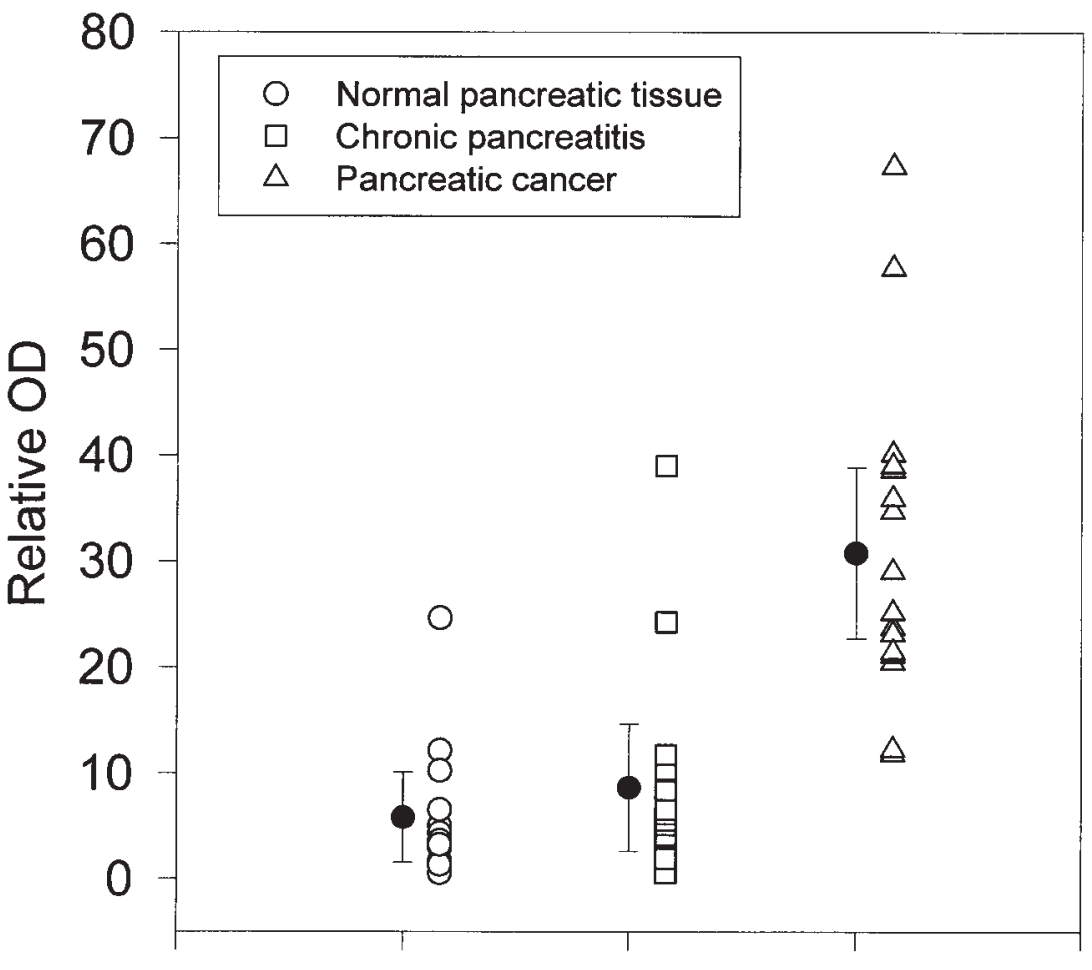

Figure 2. Relative expression of glypican-1 mRNA. Autoradiographs of Northern blots for glypican-1 and 7S RNA from 12 normal $(\bigcirc), 14$ chronic pancreatitis $(\square)$, and 16 cancerous $(\triangle)$ pancreatic tissue samples were analyzed by densitometry and the level of glypican- 1 expression was calculated as the ratio of glypican-1 and 7S RNA. Data are expressed as median glypican-1 scores (@) $\pm \mathrm{SD}$. The median glypican-1 score of the cancer samples was significantly greater than the medians from normal and chronic pancreatitis tissues $(P<0.01)$. 


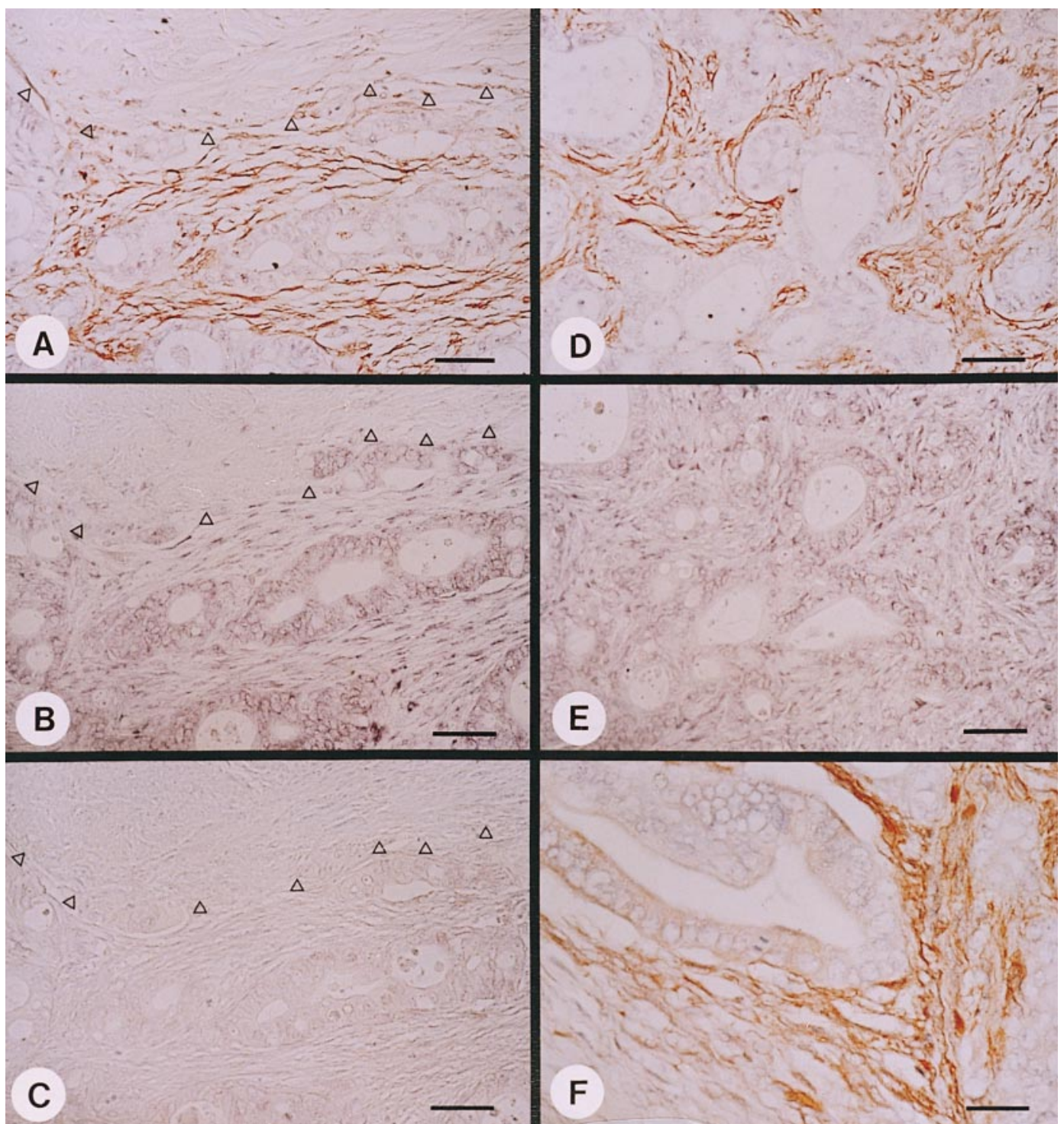

Figure 3. Immunohistochemistry and in situ hybridization analysis of glypican-1 expression in human pancreatic cancer. Strong glypican-1 immunoreactivity was present in the fibroblasts surrounding the cancer cells $(A$ and $D)$, but not in the fibroblasts that were more distant from the tumor ( $A$, arrowheads). Strong glypican-1 mRNA in situ hybridization signals were present in both the cancer cells and in the fibroblasts immediately adjacent to the cancer cells ( $B$ and $E$ ). In contrast, glypican-1 mRNA expression was not evident in the fibroblasts distant from the tumor ( $B$, arrowheads). In situ hybridization with a glypican-1 sense probe did not reveal any specific signal (C). $F$ provides a highpower magnification, revealing faint glypican-1 immunoreactivity in the ductal like cancer cells. Bars: $(A-E) 50 \mu \mathrm{m} ;(F)$ $25 \mu \mathrm{m}$. istry and in situ hybridization were carried out. In the normal pancreas and in the pancreas from individuals with chronic pancreatitis, faint to moderate glypican-1 immunoreactivity was present in a few fibroblasts (data not shown). In the pancreatic cancer samples, strong glypican-1 immunoreactivity was present in many fibroblasts that were immediately adjacent to the cancer cells (Fig. 3, $A$ and $D$ ). Faint glypican-1 immunoreactivity was also evident in some cancer cells (Fig. $3 F$ ). In contrast, by in situ hybridization, glypican-1 mRNA was strongly expressed in both the cancer cells and the adjacent fibroblasts (Fig. 3, $B$ and $E$ ). Fibroblasts distant from the cancer cells did not exhibit increased glypican-1 mRNA expression (Fig. $3 \mathrm{~B}$ ). In situ hybridization with sense probes did not produce any specific signal (Fig. $3 C$ ).

Expression of members of the glypican family in human pancreatic cancer cell lines and tissues. To determine whether cultured pancreatic cancer cells express multiple glypicans, total RNA was isolated from six pancreatic cancer cell lines. Northern blot analysis revealed high levels of glypican-1 mRNA in T3M4 and COLO-357 cells, moderate to high levels in ASPC-1 cells, and moderate to low levels in human placenta and in CAPAN-1, MIA-PaCa-2, and PANC-1 pancreatic can- cer cells (Fig. $4 A$ ). In contrast, the glypican- 4 mRNA transcripts were barely detectable in the cancer cell lines, whereas glypican-2, -3 , and -5 were below level of detection by Northern blot analysis in all the cancer cell lines (Fig. 4, $B$ and $C$, and data not shown). Glypican-3 and -4 were expressed at moderate to high levels in human placenta (Fig. 4, $B$ and $C$ ), whereas glypican-2 and -5 were also below level of detection in placenta RNA (data not shown). In view of the absence of glypican-2/-5 signals in both the pancreatic cancer cell lines and in human placenta, hybridization of human multiple tissue Northern blots was carried out with the glypican-2/-5-specific probes. As expected, the glypican-2 transcript $(\sim 4.0 \mathrm{~kb}$; Fig. $4 D$ ) was evident in human fetal brain tissue (7) and the glypican-5 transcript $(\sim 3.7 \mathrm{~kb}$, Fig. $4 E)$ was readily apparent in human adult brain tissue (10).

Immunoblotting with the anti-glypican-1 antibody revealed a $55-\mathrm{kD}$ band in all six cell lines. In general agreement with the Northern blot data, the highest levels of glypican-1 protein were observed in COLO-357 and T3M4 cells (Fig. 5 $A)$. Because heparitinase treatment was not required for demonstrating the $55-\mathrm{kD}$ protein, we next sought to confirm its identity as glypican-1 by examining the characteristics of this 


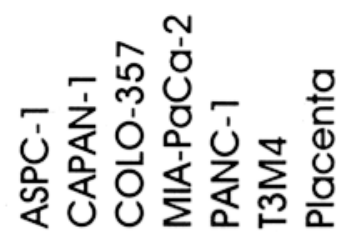

A

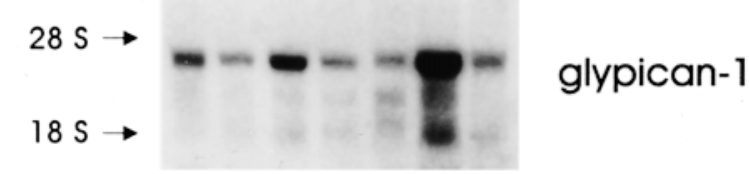

B

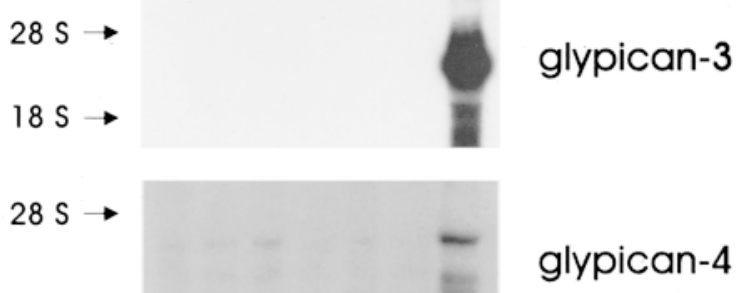

$18 \mathrm{~S} \rightarrow$

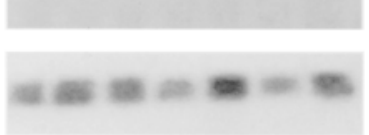

$7 S$

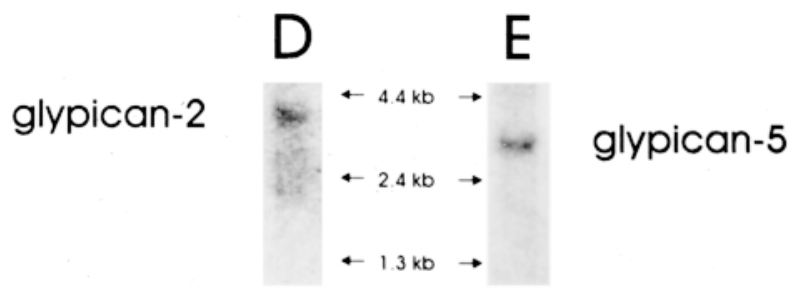

Figure 4. Expression of glypicans in cultured human pancreatic cancer cells and human placenta. Northern blots of total RNA $(20 \mu \mathrm{g} /$ lane) isolated from the indicated cell lines and placenta $(A-C)$ or polyA $^{+}$RNA $(2 \mu \mathrm{g} /$ lane $)$ isolated from fetal $(D)$ and adult $(E)$ brain tissue were hybridized with ${ }^{32} \mathrm{P}$-labeled glypican-1, $-2,-3,-4$, and -5 cDNA probes $(500,000 \mathrm{cpm} / \mathrm{ml})$ and with a $7 \mathrm{~S}$ cDNA probe $(50,000$ $\mathrm{cpm} / \mathrm{ml})$. (A) Expression of glypican-1; $(B)$ expression of glypican-3; $(C)$ expression of glypican-4; $(D)$ positive control for glypican-2 (human fetal brain tissue); $(E)$ positive control for glypican-5 (human adult brain tissue). Arrows, the $28 \mathrm{~S}$ and18S rRNA marker $(A-C)$ and RNA size markers ( $D$ and $E$ ).

protein in PANC-1 cells. First, membrane preparations (30 $\mu \mathrm{g})$ and total cell lysates $(30 \mu \mathrm{g})$ from PANC-1 cells were digested with heparitinase and subjected to SDS-PAGE followed by immunoblotting. The $55-\mathrm{kD}$ band was observed in the total protein lysate sample as well as in the membrane preparation sample (Fig. $5 \mathrm{~B})$. Second, total cell lysates $(30 \mu \mathrm{g})$ from PANC-1 cells were subjected to heparitinase digestion and analyzed by SDS-PAGE under reducing and nonreducing conditions. The 55-kD band that was observed under reducing conditions migrated as a band of $\sim 48 \mathrm{kD}$ under nonreducing conditions (Fig. 5 C). This degree of shift is characteristic of the core proteins of the glypican family, which have many disulfide bonds and migrate more rapidly under nonreducing conditions then under reducing conditions (34). Third, we isolated intact HSPGs from total cell lysates $(2.5 \mathrm{mg})$ of PANC-1 cells, using anion exchange chromatography (35). When this material was digested with heparitinase, immunoblotting revealed the presence of the $55-\mathrm{kD}$ band, whereas in the absence of heparitinase this band was not detectable (Fig. $5 D$ ). These results confirm that at least part of the total glypican-1 in PANC-1 cells bears heparan sulfate and is therefore glycanated.

To determine whether glypican-1 is released into the culture medium by pancreatic cancer cells, conditioned serumfree medium from PANC-1 and COLO-357 cells was collected during a 48-h incubation, and subjected to anion exchange chromatography to isolate HSPGs. The eluted fractions were incubated in the presence or absence of heparitinase. Immunoblot analysis revealed the presence of the $55-\mathrm{kD}$ band, representing the glypican- 1 core protein, in the heparitinase-digested sample of PANC-1 (Fig. 5 E) and COLO-357 cells (data not shown), indicating that both cells release glycanated glypican-1 into the culture medium.

Effects of cleavage of GPI anchors on growth factor action in COLO-357 and PANC-1 cells. We next sought to determine whether glypican-1 regulates growth factor action in two pancreatic cancer cell lines. COLO-357 and PANC-1 cells were incubated in the presence or absence of PI-PLC, which cleaves glypican- 1 and other proteins that associate with membranes via a covalent GPI lipid linkage. In both COLO-357 (Fig. $6 \mathrm{~A}$ ) and PANC-1 (Fig. $6 \mathrm{~B}$ ) cells, FGF2 and HB-EGF exerted a dose-dependent increase in cell proliferation. Preincubation of either cell line with PI-PLC $(0.5 \mathrm{U} / \mathrm{ml})$ and subsequent incubation with the same concentrations of FGF2 or HB-EGF in the presence of PI-PLC $(0.1 \mathrm{U} / \mathrm{ml})$ completely blocked the stimulatory effect of these heparin-binding growth factors (Fig. 6, $A$ and $B$ ). In contrast, in both cell lines PI-PLC had no significant effect on the growth stimulatory actions of EGF and IGF-I, which are non-heparin-binding growth factors (Fig. 6, $A$ and $B$ ).

In addition to removing glypican-1, PI-PLC removes other GPI-anchored proteins from the cell membrane. Therefore, we next sought to determine whether restoring glypican-1 expression could block the loss of responsiveness to heparinbinding growth factors that occurs after PI-PLC treatment. To this end, PANC-1 cells were stable transfected with a glypican-1 construct that encodes the extracellular domain of glypican-1 fused to the transmembrane domain of the VSVG, and which is therefore resistant to the actions of PI-PLC. This construct was also tagged at its $\mathrm{COOH}$ terminus with a c-myc epitope. Clones transfected with the pCDNA3.1/glyp1-VSVGTMR construct exhibited a 2.5 -kb transcript by Northern blot analysis (Fig. $7 \mathrm{~A}$ ). Expression of the fusion protein was confirmed by immunoblotting with an anti-c-myc antibody (Fig. 7 B). In addition, immunofluorescence was carried out in untreated control and pCDNA3.1/glyp1-VSVGTMR-transfected PANC-1 cells and in the respective cells after PI-PLC treatment. Relatively low intensity signals corresponding to endogenous glypican-1 were present in parental PANC-1 cells, and these signals were further decreased by PI-PLC treatment (Fig. 8, $A-D$ ). In contrast, glyp1-VSVGTMR-transfected PANC-1 cells exhibited strong glypican-1 immunofluorescence signals, which were not attenuated by PI-PLC treatment (Fig. 8, $E-G$ ).

Parental PANC-1 cells, PANC-1 cells transfected with the empty vector alone (control), and three clones expressing the glyp1-VSVGTMR construct were next incubated with growth factors in the presence or absence of PI-PLC. In both parental and control PANC-1 cells, FGF2 and HB-EGF enhanced proliferation in a dose-dependent manner, and this effect was com- 

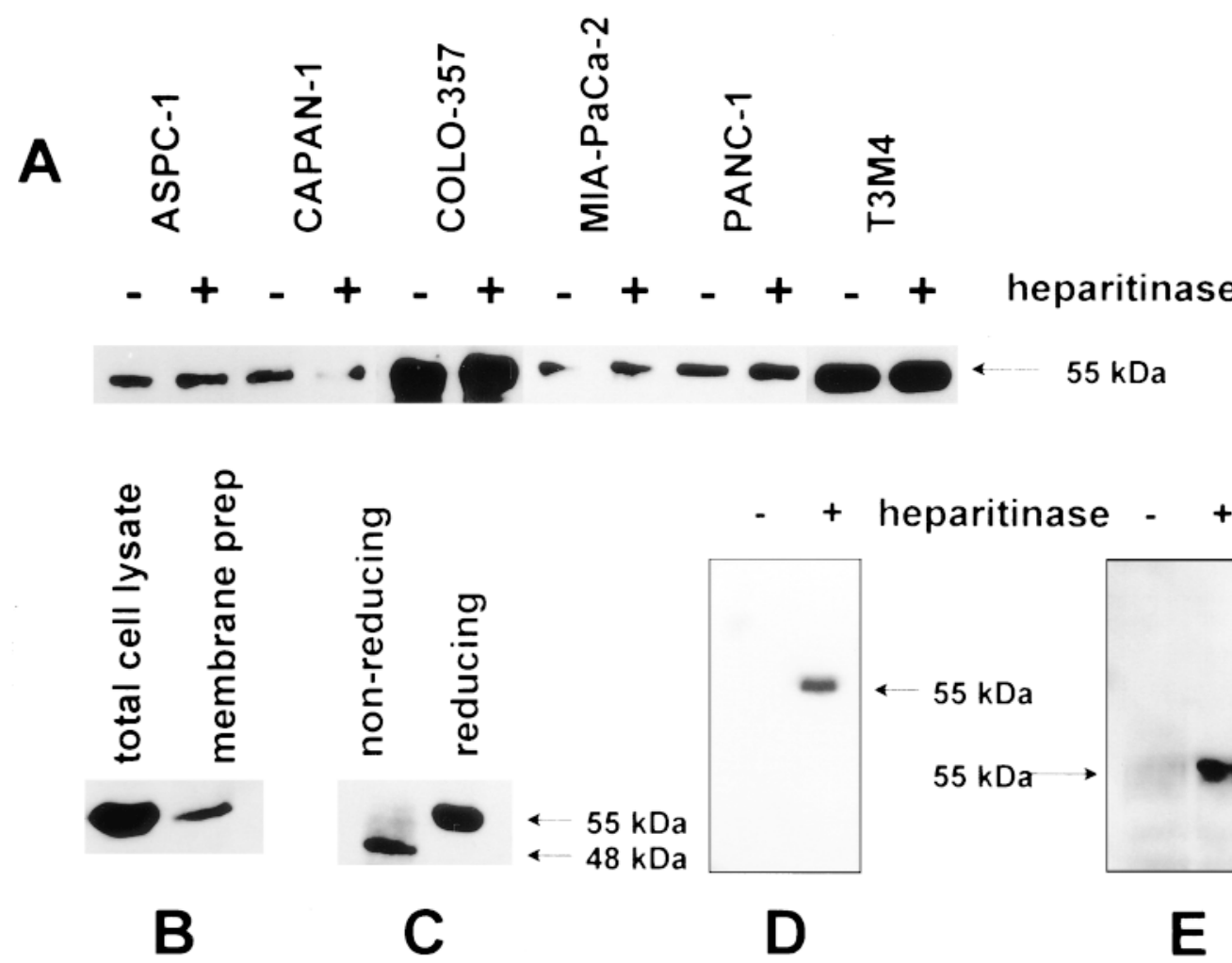

Figure 5. Glypican-1 protein expression in pancreatic cancer cell lines. (A) $30 \mu \mathrm{g}$ of total cell lysates prepared from the indicated cell lines were incubated in the absence $(-)$ or presence $(+)$ of heparitinase. (B) $30 \mu \mathrm{g}$ of total cell lysates and $30 \mu \mathrm{g}$ of membrane proteins prepared from PANC-1 cells were digested with heparitinase. $(C)$ $30 \mu \mathrm{g}$ of total cell lysates prepared from PANC-1 cells were subjected to heparitinase digestion and analyzed by SDS-PAGE under nonreducing and reducing conditions as described in Methods. (D) $2.5 \mathrm{mg}$ of total cell lysates prepared from PANC-1 cells were subjected to anion exchange chromatography and incubated in the absence $(-)$ or presence $(+)$ of heparitinase. $(E)$ PANC-1 cells were incubated for $48 \mathrm{~h}$ in serumfree medium. The conditioned serum-free medium

$(100 \mathrm{ml})$ was subjected to anion exchange chromatography and the eluted fractions were incubated in the presence $(+)$ or absence $(-)$ of heparitinase. Immunoblot analysis was carried out with an affinity purified rabbit anti-rat glypican-1 antibody ( $250 \mathrm{ng} / \mathrm{ml})$ that also recognizes human glypican-1 $(A-E)$.

A

EGF

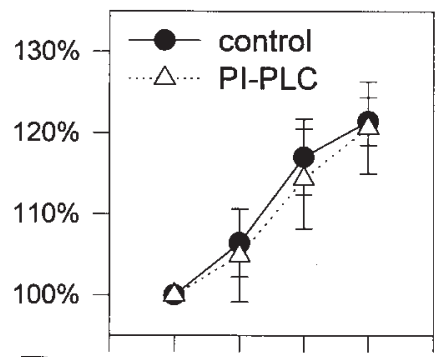

B

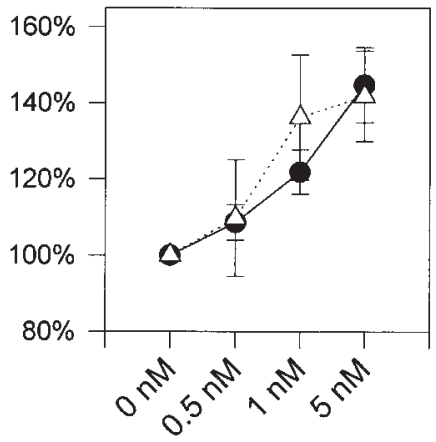

HB-EGF
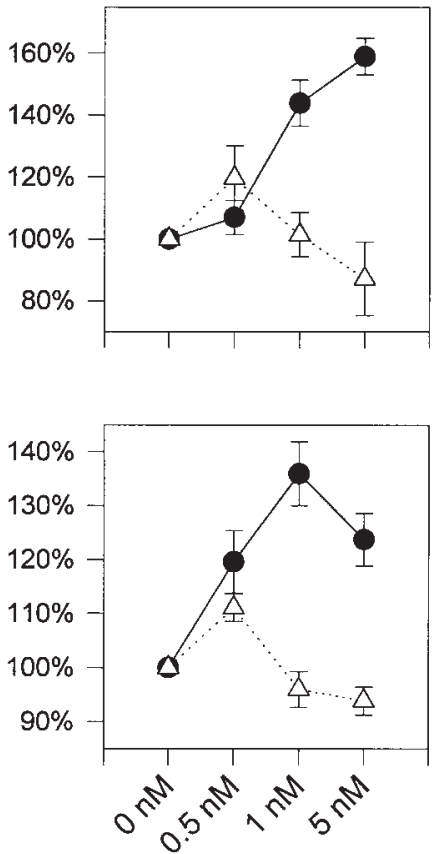

IGF-1
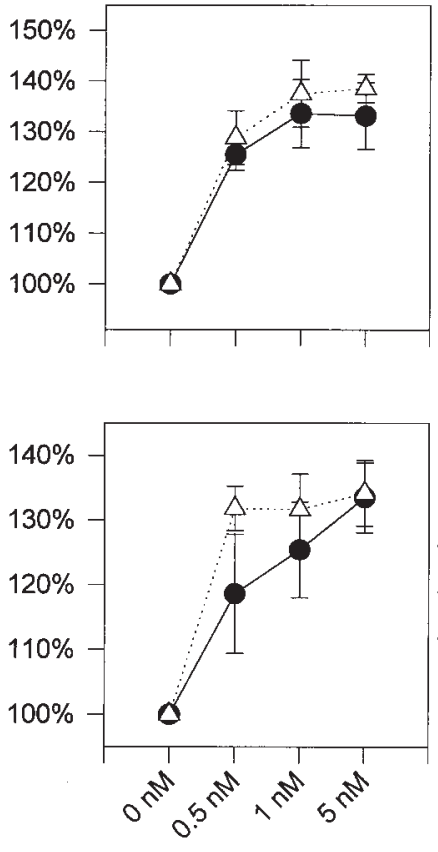

FGF2
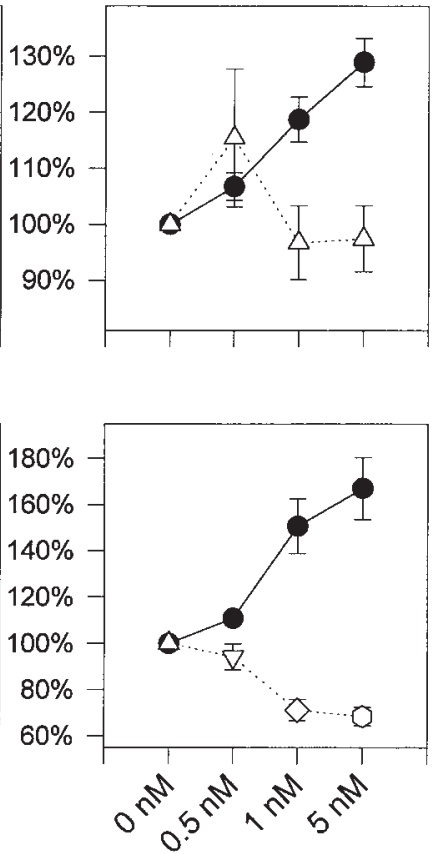

Figure 6. Effects of cleavage of GPI anchors on growth factor action in pancreatic cancer cells. PANC-1 $(A)$ and COLO-357 (B) cells were incubated with the indicated concentrations of EGF, HB-EGF, IGF-1, and FGF2 in the absence (๑) or presence ( $\triangle$ ) of PI-PLC as described in Methods. Data are expressed as percent increase or decrease of the respective untreated controls and are means \pm SEM of eight determinations per experiment from three separate experiments. 


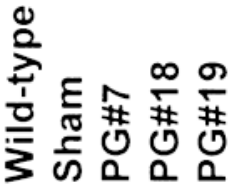

A

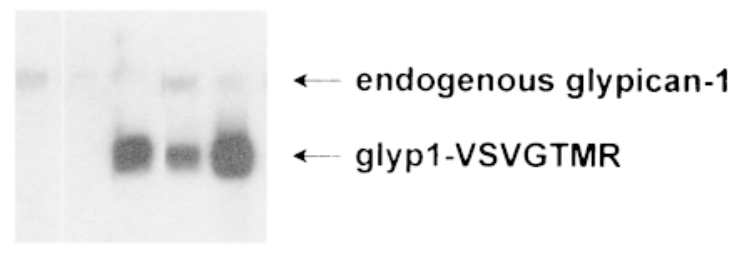

B

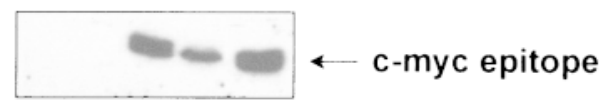

Figure 7. (A) Expression of the modified glypican-1, glyp1-VSVGTMR, in PANC-1 cells. RNA isolated from wild-type PANC-1 cells, shamtransfected PANC-1 cells, and three pCDNA3.1/glyp1-VSVGTMR clones $(20 \mu \mathrm{g})$ were subjected to Northern blot analysis using a ${ }^{32} \mathrm{P}-$ labeled glypican- $1 \mathrm{cDNA}$ probe $(500,000 \mathrm{cpm} / \mathrm{ml})$. Exposure time was $12 \mathrm{~h}$. Low levels of the endogenous glypican-1 transcript $(3.5 \mathrm{~kb})$ are seen in all cells. High levels of the glyp1-VSVGTMR transcript $(2.5 \mathrm{~kb})$ are seen only in the transfected clones. (B) Immunoblot analysis using an anti-c-myc antibody recognizing the c-myc epitope of the glyp1-VSVGTMR construct confirmed protein expression of glyp1-VSVGTMR in the transfected clones.

pletely blocked by PI-PLC treatment (Fig. 9). In contrast, in the three glyp1-VSVGTMR-expressing clones, PI-PLC did not significantly alter the growth stimulatory actions of FGF2 and HBEGF (Fig. 9). Since the glyp1-VSVGTMR construct prevented PI-PLC from blocking heparin-binding growth factor respon- siveness, the effects of PI-PLC in parental PANC-1 cells were most likely due to its ability to cleave endogenous glypican- 1 .

Effects of reduced glypican-1 protein levels on growth factor responsiveness in PANC-1 cells. To determine whether it is possible to modulate responsiveness to heparin-binding growth factors by altering endogenous glypican-1 protein levels, we next transiently transfected PANC-1 cells with a glypican-1 antisense construct (G1-AS-1751). After transient transfection, there was a time- and dose-dependent appearance of glypican-1 antisense mRNA, as determined by Northern blot analysis with a specific glypican-1 sense riboprobe (Fig. $10 A$ ). After transfection with $10 \mu \mathrm{g}$ plasmid DNA/4 $\times 10^{6}$ cells, expression of the glypican-1 antisense mRNA was evident within $24 \mathrm{~h}$. Peak expression occurred after $48 \mathrm{~h}$, and was sustained for at least $96 \mathrm{~h}$ (Fig. $10 \mathrm{~A}$ ). Immunoblot analysis with the highly specific glypican-1 antibody indicated that there was a parallel decrease in glypican-1 protein levels (Fig. $10 \mathrm{~B}$ ). A slight decrease was evident after $24 \mathrm{~h}$, whereas maximal reduction of glypican-1 protein levels occurred at 48-96 h (Fig. 10 B). Next, the effects of growth factors on cell growth were determined during the 48-96 $\mathrm{h}$ interval after transfection, when glypican-1 protein levels were maximally reduced. The growth stimulatory actions of EGF and IGF-1 were not significantly different from control, sham-transfected, and G1-AS-1751-transfected PANC-1 cells (Fig. 11). In contrast, the growth stimulatory effects of FGF2 and HB-EGF were completely blocked in the G1-AS-1751-transfected PANC-1 cells (Fig. 11), whereas both growth factors enhanced cell proliferation in a dose-dependent manner in control and sham-transfected PANC-1 cells (Fig. 11).

\section{Discussion}

HSPGs are thought to play an important role in growth factor signaling, a role that has been particularly well documented for
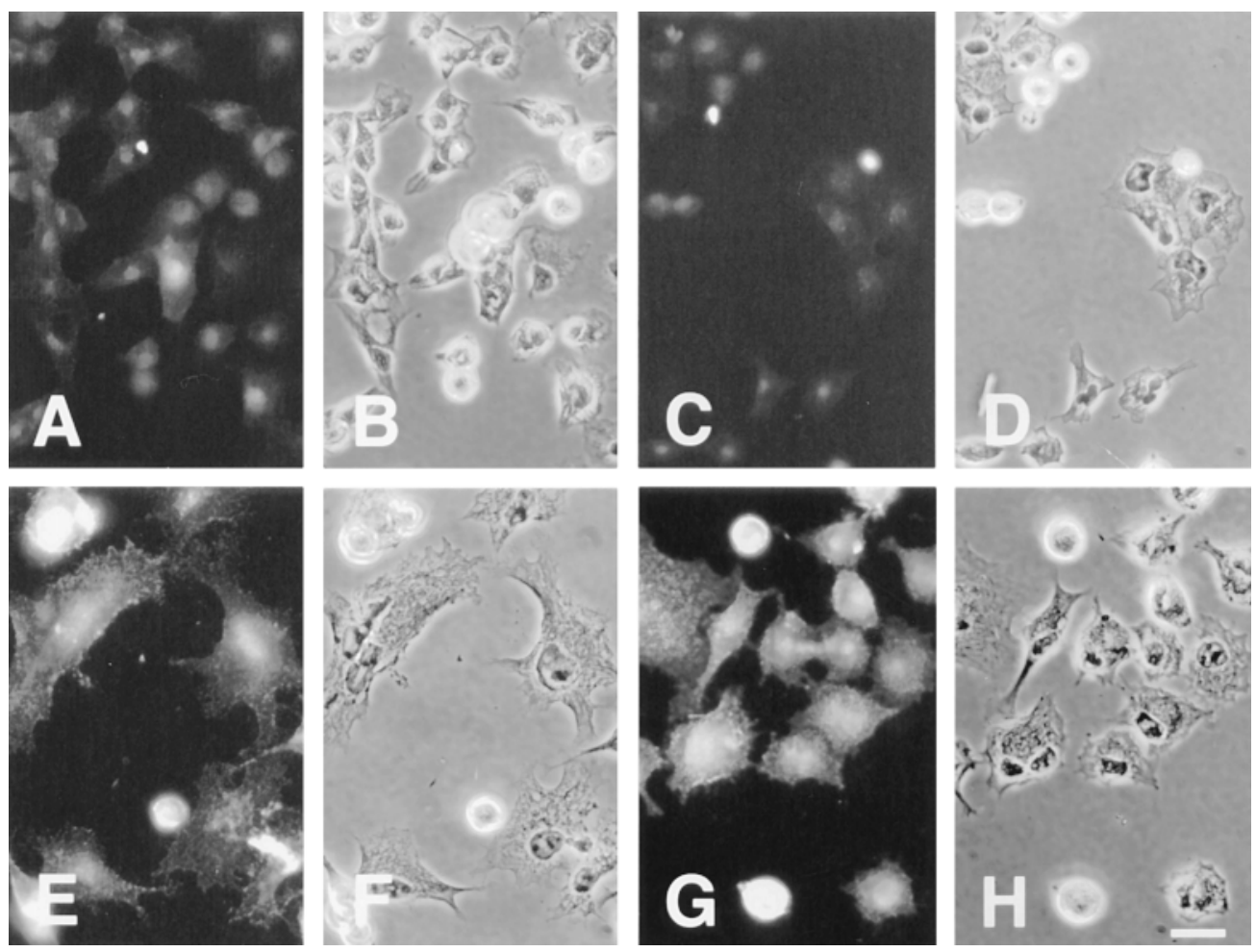

Figure 8. Effects of PI-PLC treatment on glypican-1 immunofluorescence in cultured cells. Sham-transfected $(A-D)$ and glyp1-VSVGTMR-transfected PANC-1 cells $(E-H)$ were incubated for $1 \mathrm{~h}$ in the absence $(A$, $B, E$, and $F)$ or presence $(C, D$, $G$, and $H$ ) of PI-PLC $(0.5 \mathrm{U} / \mathrm{ml})$, and stained with an affinity-purified rabbit anti-rat glypican-1 antibody followed by addition of Cy3-conjugated anti-rabbit antibody. Immunofluorescence ( $A$, $C, E$, and $G$ ) and the corresponding phase-contrast images $(B, D$, $F$, and $H$ ) are shown. Bar: $30 \mu \mathrm{m}$. 


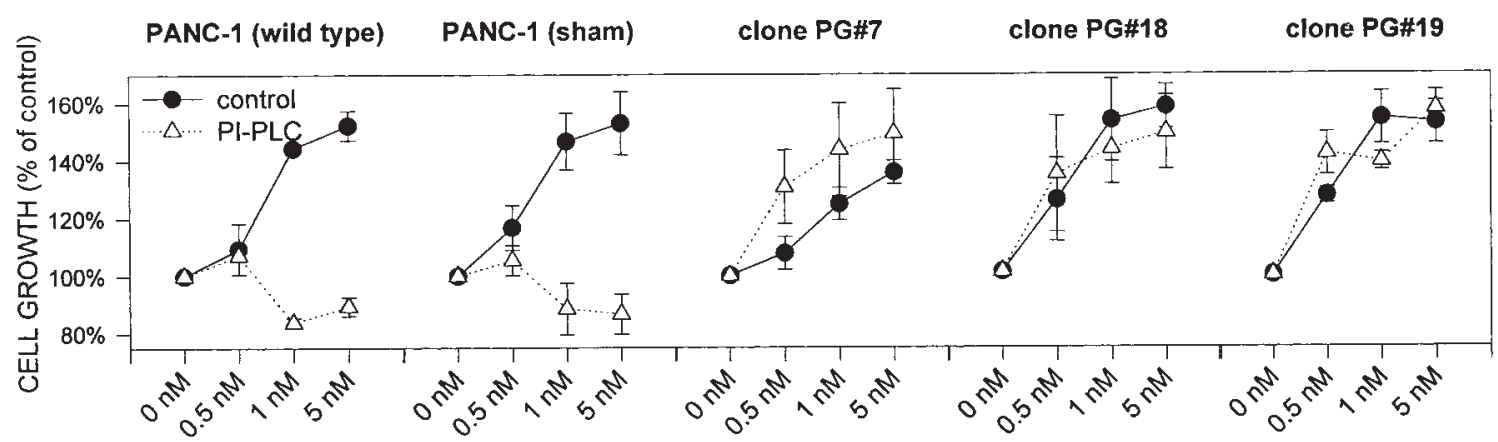

$\mathrm{B}$

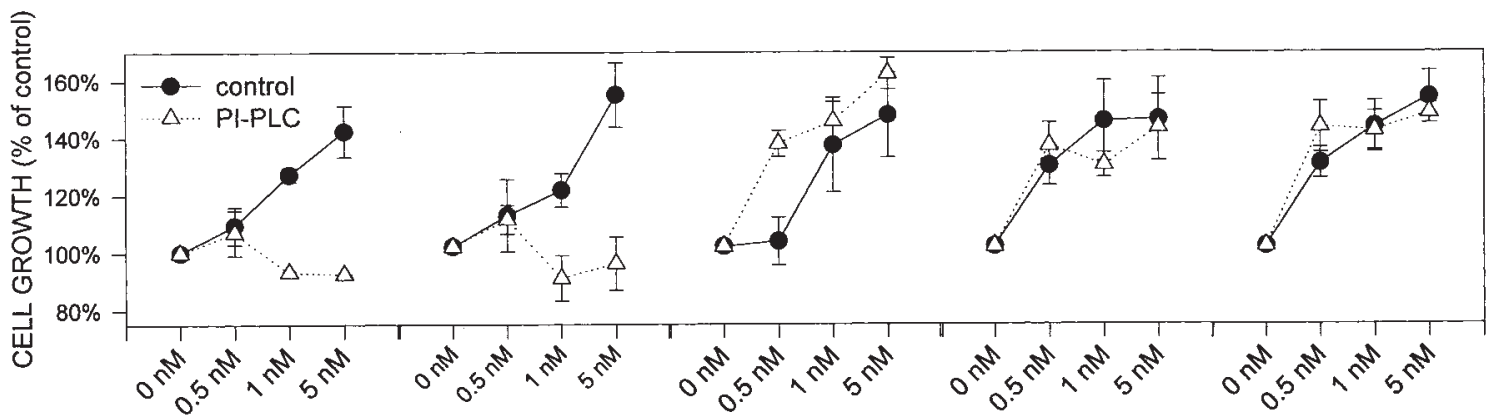

Figure 9. Effects of glyp1-VSVGTMR on PI-PLC-mediated inhibition of heparin-binding growth factor action. Wild-type PANC-1 cells, shamtransfected PANC-1 cells, and three pCDNA3.1/glyp1-VSVGTMR-transfected PANC-1 clones were incubated with the indicated concentrations of HB-EGF $(A)$, and FGF2 $(B)$ in the absence $(\bullet)$ or presence $(\triangle)$ of PI-PLC as described in Methods. Data are expressed as percent increase or decrease of unstimulated controls and are means \pm SEM of eight determinations per experiment from three separate experiments.

FGFs (15-17). HSPGs are essential for the interactions of FGFs with their high affinity receptors in a number of cell types, including Chinese hamster ovary (CHO) cells (16), 3T3 fibroblasts (15), lymphoid cells (36), myeloblasts (37), chondrocytes (38), and MCF-7 breast cancer cells (39). HSPGs may act by increasing the affinity of FGFs for their receptors (4, 40), facilitating receptor dimerization and subsequent signaling (41-43), and/or stabilizing FGFs by protecting them from proteolysis or thermal denaturation $(44,45)$. HSPGs have also been shown to be essential for mitogenic signaling of HB-EGF in rat vascular smooth muscle cells (18) and rat gastric mucosal cells (46), and may serve as coreceptors for a variety of other secreted growth factors including vascular endothelial growth factor, hepatocyte growth factor, and members of the Wnt, TGF- $\beta$, and hedgehog families (19-21, 47). Furthermore, HSPGs of the glypican family, glypican-3 and Drosophila dally, have been implicated in the control of cellular growth. Mutations in dally produce morphological defects in certain fly tissues by affecting patterned cell divisions (48), and glypican-3 mutations cause the Simpson-Golabi-Behmel overgrowth syndrome in humans $(49,50)$.

In this study we determined that human pancreatic cancers

A

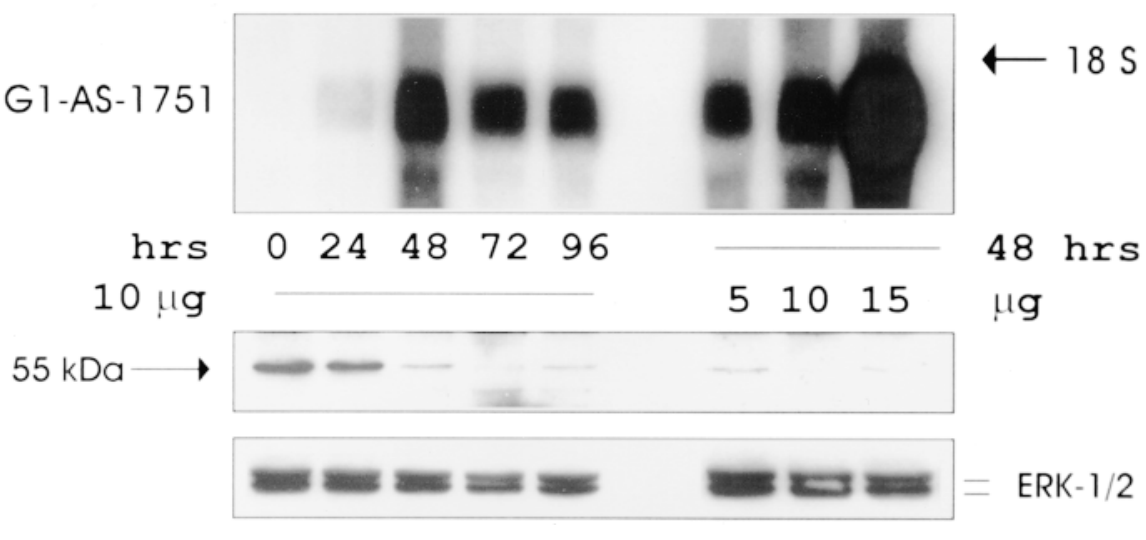

Figure 10. Expression of glypican-1 antisense (G1-AS-1751) mRNA and glypican-1 protein in PANC-1 cells. Total RNA $(20 \mu \mathrm{g} / \mathrm{lane})$ and total cell lysates $(30 \mu \mathrm{g} / \mathrm{lane})$ were isolated from PANC-1 cells at the indicated times after transfection with the indicated amounts of pMH6/G1AS-1751 plasmid DNA (the total amount of transfected DNA was equal in all samples). ( $A$ ) Northern blots were hybridized with a ${ }^{32} \mathrm{P}$ labeled glypican-1 sense riboprobe $(500,000 \mathrm{cpm} / \mathrm{ml})$. Exposure time was $6 \mathrm{~h}$. Equal loading was determined by ethidium bromide staining. (B) Immunoblot analysis was carried using the affinity purified rabbit anti-rat glypican-1 antibody $(250 \mathrm{ng} / \mathrm{ml})$ that also recognizes human glypican- 1 . To confirm equal loading, the membrane was stripped and reprobed with an anti-ERK-1 antibody that crossreacts with ERK-2. The positions of ERK-1 (p44) and ERK-2 (p42) are indicated on the right. 

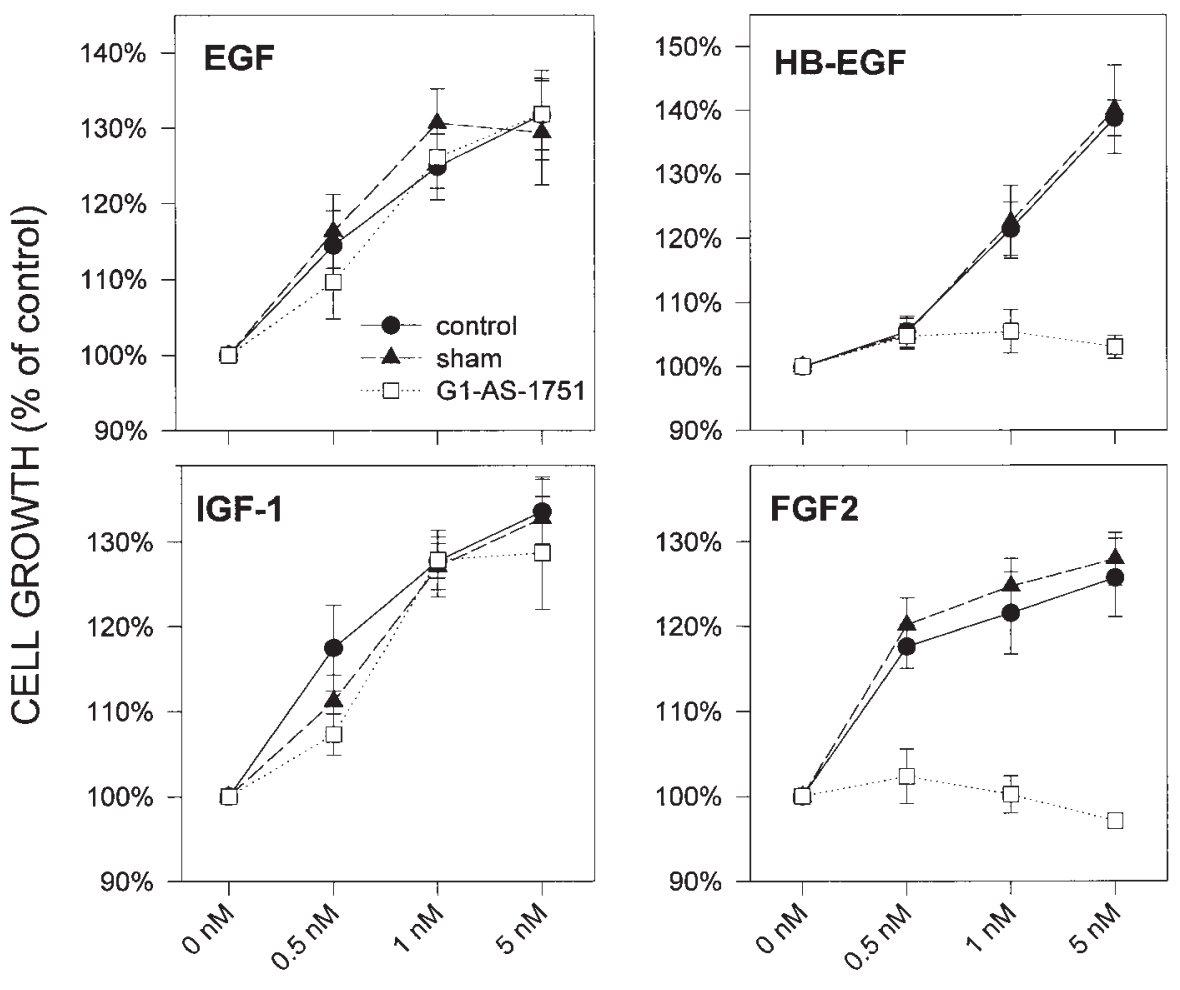

Figure 11. Effects of G1-AS-1751 on growth factor action in PANC-1 cells. PANC-1 cells $(-)$, PANC-1 cells transfected with equivalent amounts of $\mathrm{pMH}$ DNA $(\mathbf{\Delta})$, and G1-AS-1751-transfected PANC-1 cells $(\square)$ were incubated for $48 \mathrm{~h}$ with the indicated concentrations of EGF, HB-EGF, IGF-1, and FGF2. Data are expressed as percent change from unstimulated controls and are means \pm SEM of eight determinations per experiment from three separate experiments. overexpress glypican-1 at both the mRNA and protein levels. By Northern blot analysis, there was an eightfold increase in glypican-1 mRNA levels in the cancer tissues. None of the cancer samples exhibited an abnormal-sized glypican-1 transcript. Western blot analysis revealed the anticipated $55-\mathrm{kD}$ core protein in four of six cancer samples, but in none of the tested normal samples. The 55-kD glypican-1 core protein was evident only after heparitinase treatment, which is in agreement with the observation in other tissues that intact glypican-1 migrates as a broad high mol wt smear on SDS-PAGE $(12,28,35)$. These findings indicate that the majority of glypican- 1 in pancreatic cancer tissues is glycosylated with heparan sulfate.

Only faint glypican-1 immunoreactivity was evident in the pancreatic cancer cells within the tumor mass. In contrast, the fibroblasts immediately adjacent to the cancer cells exhibited intense glypican-1 immunoreactivity. However, by in situ hybridization, glypican-1 was expressed at high levels in both the cancer cells and the adjoining fibroblasts. Inasmuch as glypican- 1 is known to exist on the surface of cells as both a lipidanchored form and as a peripheral membrane proteoglycan (51) most likely derived by shedding (39), these observations suggest that some of the glypican-1 that is associated with fibroblasts surrounding pancreatic cancer cells in vivo is derived from the cancer cells. This conclusion is supported by the observation that all six pancreatic cancer cell lines expressed abundant amounts of glypican-1 mRNA and protein, and that glypican-1 was present in the conditioned medium of both tested cell lines, PANC-1 and COLO-357.

Immunoblotting with a glypican-1-specific antibody revealed the presence of a $55-\mathrm{kD}$ protein in the pancreatic cancer cell lines, even in the absence of heparitinase digestion. Nonetheless, three lines of evidence suggest that this protein is glypican-1. First, Western blotting demonstrated the presence of this protein in membrane preparations. Second, under non- reducing conditions, the $55-\mathrm{kD}$ protein migrated as a band of $\sim 48 \mathrm{kD}$. This is characteristic of glypicans, which are highly disulfide-bonded and exhibit greater mobility in nonreducing gels (34). Third, purification of HSPGs from total cell lysates by anion exchange chromatography demonstrated that at least some glycanated (heparan sulfate-bearing) glypican-1 is made by these cells. Together, these observations suggest that some of the glypican-1 synthesized by cultured pancreatic cancer cells is not glycanated, as can occur in cells engineered to produce abnormally high levels of HSPG core proteins (our unpublished observations). Alternatively, it is possible that some of the heparan sulfate chains on glypican-1 are removed postsynthetically by the cancer cells. Consistent with the latter possibility, it is known that cancer cells of many types, especially those with high metastatic potential, release high levels of heparanases, enzymes that degrade heparan sulfate (52-55).

Previous work has established that a variety of polypeptide growth factors and their receptors are overexpressed in human pancreatic cancer (25), including heparin-binding growth factors such as FGF2 (24) and HB-EGF (26). These growth factors enhance the proliferation of cultured human pancreatic cancer cell lines in vitro and it has been suggested that aberrant autocrine and paracrine activation of mitogenic pathways by these growth factors may contribute to pancreatic cancer cell growth in vivo. Inasmuch as heparin-dependent growth factors can be stored in the extracellular matrix to protect them against proteolytic degradation (43), the abundance of glypican-1 in the fibroblasts surrounding the tumor suggests that it may participate in the storage of these growth factors. As cancer cells invade this stroma, it is possible that these growth factors are released (e.g., by heparanases) for subsequent mitogenic stimulation of the cancer cells. It is conceivable, however, that glypican-1 present on fibroblasts adjacent to the tumor may also act to dampen the mitogenic response to 
these growth factors. For example, in keratinocytes, glypican-1 enhances the mitogenic response to FGF1 while inhibiting the mitogenic response to FGF7 (17). Furthermore, inhibiting proteoglycan sulfation in MDA-MB-231 human breast cancer cells decreases binding of FGF2 to HSPGs and restores responsiveness to FGF2 mitogenic signals (39).

Three lines of evidence suggest that glypican-1 plays an important role in FGF2 and HB-EGF signaling in pancreatic carcinoma cell lines. First, treatment of COLO-357 and PANC-1 pancreatic cancer cells with PI-PLC abrogated selectively the mitogenic effects of FGF2 and HB-EGF in these cell lines, implying that a GPI-anchored molecule plays an essential role in FGF2- and HB-EGF- (but not IGF-1- or EGF-) mediated signaling. Second, FGF2 and HB-EGF mitogenesis were unaffected by PI-PLC in PANC-1 cells that have been engineered to express a transmembrane-anchored form of glypican-1. Since glypicans are the only known GPI-anchored HSPGs, and the expression levels of glypicans $-2,-3,-4$, or -5 are exceedingly low in pancreatic cancer cell lines, we conclude that endogenous glypican-1 (or another GPI-anchored molecule for which glypican-1 can substitute) is the PI-PLC-sensitive molecule that is normally required for such growth factor signaling. Third, reduction of glypican-1 protein levels in PANC-1 after expression of a glypican-1 antisense construct was associated with a marked attenuation of the mitogenic effects of FGF2 and HB-EGF in these cells, without altering EGF- and IGF-1induced mitogenesis.

HB-EGF and EGF signal by activating the same receptors, which are members of the EGF receptor family $(56,57)$. However, only HB-EGF signaling was abrogated by PI-PLC. This observation suggests that the requirement for glypican- 1 is at or upstream of the level of the receptor, precisely what one would expect for a molecule that acts by modulating or modifying growth factor-receptor interactions (i.e., a coreceptor). Apparently, non-GPI-anchored HSPGs (e.g., a syndecan) on the surface of pancreatic carcinoma cells do not support this function in the absence of glypican-1, a result that is somewhat surprising given the fact that transfected syndecans are known to be able to confer FGF2 sensitivity upon HSPG-deficient cells (58). It is possible, therefore, that pancreatic carcinoma cells are lacking in syndecans, or alternatively, that the coreceptor functions of glypicans and syndecans are not interchangeable.

Because of the potentially widespread roles of cell surface HSPGs in growth factor signaling, it is tempting to speculate that upregulation of HSPG expression would be common in malignancies, yet this is apparently not the case. Instead, a decrease in the expression of cell surface HSPGs, the amount of heparan sulfate, the fraction of total glycosaminoglycan present as heparan sulfate, and the extent of sulfation of heparan sulfate, has been reported in association with cancers of the bladder, prostate, and lung (59-62) and with the oncogenic activation of cells in vitro (63). Furthermore, in squamous cell carcinomas, the level of syndecan-1 correlates inversely with tumor grade, stage and clinical outcome (64). It will be interesting to determine whether the upregulation of glypican-1 in pancreatic cancer is a unique feature of this neoplasm.

The fact that glypican-1 is not upregulated either in fibroblasts distant from the cancer cells, or in fibroblasts in chronic pancreatitis, even though this condition is associated with increased growth factor expression and the production of excessive stroma $(65,66)$, points to an important paracrine interac- tion between pancreatic cancer cells and the adjacent fibroblasts. Together with the observation that glypican-1 is essential for mitogenic signaling of FGF2 and HB-EGF in pancreatic cancer cells, our findings raise the possibility that glypican-1 plays a crucial role in neoplastic transformation and tumor progression in this malignancy.

\section{Acknowledgments}

This work was supported by U.S. Public Health Service grants CA40162 to M. Korc and NS-26862 to A.D. Lander. J. Kleeff was the recipient of a fellowship award from the University of California Research and Education grant on Gene Therapy for Cancer.

\section{References}

1. LeBaron, R.G., A. Höök, J.D. Esko, S. Gay, and M. Höök. 1989. Binding of heparan sulfate to type V collagen. A mechanism of cell-substrate adhesion. J. Biol. Chem. 264:7950-7956.

2. Stanley, M.J., B.F. Liebersbach, W. Liu, D.J. Anhalt, and R.D. Sanderson. 1995. Heparan sulfate mediated cell aggregation syndecans-1 and -4 mediate intercellular adhesion following their transfection into human B-lymphoid cells. J. Biol. Chem. 10:5077-5083.

3. David, G. 1993. Integral membrane heparan sulfate proteoglycans. FASEB J. 7:1023-1030.

4. Rapraeger, A.C., S. Guimond, A. Krufka, and B.B. Olwin. 1994. Regulation by heparan sulfate in fibroblast growth factor signaling. Methods Enzymol. 245:219-240.

5. Bernfield, M., R. Kokenyesi, M. Kato, M.T. Hinkes, J. Spring, R.L. Gallo, and E.J. Lose. 1992. Biology of the syndecans: a family of transmembrane heparan sulfate proteoglycans. Ann. Rev. Cell Biol. 8:365-393.

6. David, G., V. Lorie, B. Decock, P. Marynen, J.-J. Cassiman, and H. Van den Berghe. 1990. Molecular cloning of a phosphatidylinositol-anchored membrane heparan sulfate proteoglycan from human lung fibroblasts. J. Cell Biol. 111:3165-3176.

7. Stipp, C.S., E.D. Litwack, and A.D. Lander. 1994. Cerebroglycan: an integral membrane heparan sulfate proteoglycan that is unique to the developing nervous system and expressed specifically during neuronal differentiation. $J$. Cell Biol. 124:149-160.

8. Filmus, J., J.G. Church, and R.N. Buick. 1988. Isolation of a cDNA corresponding to a developmentally regulated transcript in rat intestine. Mol. Cell. Biol. 8:4243-4249.

9. Watanabe, K., H. Yamada, and Y. Yamaguchi. 1995. K-glypican: a novel GPI-anchored heparan sulfate proteoglycan that is highly expressed in developing brain and kidney. J. Cell Biol. 130:1207-1218.

10. Saunders, S., S. Paine-Saunders, and A.D. Lander. 1997. Expression of the cell surface glypican-5 is developmentally regulated in kidney, limb, and brain. Dev. Biol. 190:78-93.

11. Ivins, J.K., E.D. Litwack, A. Kumbasar, C.S. Stipp, and A.D. Lander. 1997. Cerebroglycan, a developmentally regulated cell-surface heparan sulfate proteoglycan, is expressed on developing axons and growth cones. Dev. Biol. 184:320-332.

12. Litwack, E.D., J.K. Ivins, A. Kumbasar, S. Paine-Saunders, C.S. Stipp, and A.D. Lander. 1998. Expression of the heparan sulfate proteoglycan glypican-1 in the developing rodent. Dev. Dynamics. 211:72-87.

13. Asundi, V.K., B.F. Keister, R.C. Stahl, and D.J. Carey. 1997. Developmental and cell-type-specific expression of cell surface heparan sulfate proteoglycans in the rat heart. Exp. Cell Res. 230:145-153.

14. Carey, D.J., and D.M. Evans. 1989. Membrane anchoring of heparan sulfate proteoglycans by phosphatidylinositol and kinetics of synthesis of peripheral and detergent-solubilized proteoglycans in Schwann cells. J. Cell Biol. 108:1891-1897.

15. Rapraeger, A.C., M. Jalkanen, E. Endo, J. Koda, and M. Bernfield. 1995. The cell surface proteoglycan from mouse mammary epithelial cells bears chondroitin sulfate and heparan sulfate glycosaminoglycans. J. Biol. Chem. 260: 11046-11052.

16. Yayon, A., M. Klagsbrun, J.D. Esko, P. Leder, and D.M. Ornitz. 1991 Cell surface, heparin-like molecules are required for binding of basic fibroblast growth factor to its high affinity receptor. Cell. 64:841-848.

17. Bonneh-Barkey, D., M. Shlissel, B. Berman, E. Shaoul, A. Admont, I Vlodavsky, D.J. Carey, V.K. Asundi, R. Reich-Slotky, and D. Ron. 1997. Identification of glypican as a dual modulator of the biological activity of fibroblast growth factors. J. Biol. Chem. 272:12415-12421.

18. Fukuda, K., Y. Inui, S. Kawata, S. Higashiyama, Y. Matsuda, Y. Maeda, T. Igura, S. Yoshida, N. Tanaguchi, and Y. Matsuzawa. 1995. Increased mitogenic response to heparin-binding epidermal growth factor-like growth factor in vascular smooth muscle cells of diabetic rats. Arterioscler. Thromb. Vasc. Biol. 
15:1680-1687.

19. Sakata, H., S.J. Stahl, W.G. Taylor, J.M. Rosenberg, K. Sakaguchi, P.T. Wingfield, and J.S. Rubin. 1997. Heparin binding and oligomerization of hepatocyte growth factor/scatter factor isoforms. Heparan sulfate glycosaminoglycan requirement for Met binding and signaling. J. Biol. Chem. 272:9457-9463.

20. Itoh, K., and S.Y. Sokol. 1994. Heparan sulfate proteoglycans are required for mesoderm formation in Xenopus embryos. Development. 120:27032711.

21. Reichsman, F., L. Smith, and S. Cumberledge. 1996. Glycosaminoglycans can modulate extracellular localization of the wingless protein and promote signal transduction. J. Cell Biol. 135:819-827.

22. Warshaw, A.L., and C. Fernandez-del Castillo. 1992. Pancreatic carcinoma. N. Engl. J. Med. 326:455-465.

23. Korc, M. 1996. Growth factors in pancreatic cancer. In Advances in Pancreatic Disease. C.G. Dervenis, editor. Georg Thieme Verlag Stuttgart, New York. 34-41.

24. Yamanaka, Y., H. Friess, M. Büchler, H.G. Beger, E. Uchida, M. Onda, M.S. Kobrin, and M. Korc. 1993. Overexpression of acidic and basic fibroblast growth factors in human pancreatic cancer correlates with advanced tumor stage. Cancer Res. 53:5289-5296.

25. Ebert, M., M. Yokoyama, M.S. Kobrin, H. Friess, M.E. Lopez, M.W. Büchler, G.R. Johnson, and M. Korc. 1994. Induction and expression of amphiregulin in human pancreatic cancer. Cancer Res. 54:3959-3962.

26. Kobrin, M.S., H. Funatomi, H. Friess, M.W. Büchler, P. Stathis, and M. Korc. 1994. Induction and expression of heparin-binding EGF-like growth factor in human pancreatic cancer. Biochem. Biophys. Res. Commun. 202:17051709.

27. Kornmann, M., T. Ishiwata, H.G. Beger, and M. Korc. 1997. Fibroblast growth factor-5 stimulates mitogenic signaling and is overexpressed in human pancreatic cancer: evidence for autocrine and paracrine actions. Oncogene. 15: $1417-1424$.

28. Litwack, E.D., C.S. Stipp, A. Kumbasar, and A.D. Lander. 1994. Neuronal expression of glypican, a cell-surface glycosylphosphatidylinositol-anchored heparan sulfate proteoglycan, in the adult rat nervous system. J. Neuroscience. 14:3713-3724

29. Arreaza, G., and D.A. Brown. 1995. Sorting and intracellular trafficking of a glycosylphosphatidylinositol-anchored protein and two hybrid transmembrane proteins with the same ectodomain in Madin-Darby canine kidney epithelial cells. J. Biol. Chem. 270:23641-23647.

30. Korc, M., B. Chandrasekar, Y. Yamanaka, H. Friess, M.W. Büchler, and H.G. Beger. 1992. Overexpression of the epidermal growth factor receptor in human pancreatic cancer is associated with concomitant increase in the levels of epidermal growth factor and transforming growth factor alpha. J. Clin. Invest. 90:1352-1360.

31. Raitano, A.B., and M. Korc. 1990. Tumor necrosis factor up-regulates $\gamma$-interferon binding in a human carcinoma cell line. J. Biol. Chem. 265:1046610472.

32. Baldwin, R.L., and M. Korc. 1993. Growth inhibition of human pancreatic carcinoma cells by transforming growth factor beta-1. Growth Factors. 8: 23-34.

33. Rapraeger, A.C., A. Krufka, and B.B. Olwin. 1991. Requirement of heparan sulfate for bFGF-mediated fibroblast growth and myoblast differentiation. Science. 252:1705-1708.

34. Lander, A.D., C.S. Stipp, and J.K. Ivins. 1995. The glypican family of heparan sulfate proteoglycans: major cell-surface proteoglycans of the developing nervous system. Perspect. Dev. Neurobiol. 1:1-7.

35. Herndon, M.E., and A.D. Lander. 1990. A diverse set of developmentally regulated proteoglycans is expressed in the rat central nervous system. Neuron. 4:949-961.

36. Ornitz, D.M., A. Yayon, J.G. Flanagan, C.M. Svahn, E. Levi, and P. Leder. 1992. Heparin is required for cell-free binding of basic fibroblast growth factor to a soluble receptor and for mitogenesis in whole cells. Mol. Cell. Biol. 12:240-247.

37. Olwin, B.B., and A. Rapraeger. 1992. Repression of myogenic differentiation by aFGF, bFGF, and K-FGF is dependent on cellular heparan sulfate. $J$. Cell Biol. 118:631-639.

38. Chintala, S.K., R.R. Miller, and C.A. McDevitt. 1995. Role of heparan sulfate in the terminal differentiation of growth plate chondrocytes. Arch. Biochem. Biophys. 316:227-234.

39. Delhedde, M., E. Deudon, B. Boilly, and H. Hondermarck. 1996. Heparan sulfate proteoglycans play a dual role in regulating fibroblast growth factor-2 mitogenic activity in human breast cancer cells. Exp. Cell Res. 229:398-406.

40. Roghani, M., A. Mansukhani, P. Dell'Era, P. Bellosta, C. Basilico, and D. Moscatelli. 1994. Heparin increases the affinity of basic fibroblast growth factor for its receptor but is not required for binding. J. Biol. Chem. 269:39763984.

41. Spivak-Kroizman, T., M.A. Lemmon, I. Dikic, J.E. Landbury, D. Pinchasi, J. Huang, M. Jaye, C. Crumley, J. Schlessinger, and I. Lax. 1994. Heparininduced oligomerization of FGF molecules is responsible for FGF receptor dimerization, activation, and cell proliferation. Cell. 79:1015-1024.
42. Pantoliano, M.W., R.A. Horlick, B.A. Springer, D.E. Van Dick, T. Tobery, D.R. Wetmore, J.D. Lear, A.T. Nahapetian, J.D. Bradley, and W.O. Sisk 1994. Multivalent ligand-receptor binding interactions in the fibroblast growth factor system produce a cooperative growth factor and heparin mechanism for receptor dimerization. Biochemistry. 33:10229-10248.

43. Schlessinger, J., I. Lax, and M. Lemmon. 1995. Regulation of growth factor activation by proteoglycans: what is the role of the low affinity receptors? Cell. 83:357-360.

44. Saksela, O., and D.B. Rifkin. 1990. Release of basic fibroblast growth factor-heparan sulfate complexes from endothelial cells by plasminogen activator-mediated proteolytic activity. J. Cell Biol. 110:767-775.

45. Vlodavsky, I., H.-Q. Miao, B. Medalion, P. Danagher, and D. Ron. 1996. Involvement of heparan sulfate and related molecules in sequestration and growth promoting activity of fibroblast growth factor. Cancer Metastasis Rev. 15:177-186.

46. Miyaza, Y., Y. Shinomura, S. Higashiyma, S. Kanayama, Y. Higashimoto, S. Tsutsui, S. Zushi, N. Taniguchi, and Y. Matsuzawa. 1996. Heparin-binding EGF-like growth factor is an autocrine growth factor for rat gastric epithelial cells. Biochem. Biophys. Res. Commun. 223:36-41.

47. Chiang, M.K., and J.G. Flanagan. 1995. Interactions between the Flk-1 receptor, vascular endothelial growth factor, and cell surface proteoglycan identified with a soluble receptor reagent. Growth Factors. 12:1-10.

48. Nakato, H., T.A. Futch, and S.B. Selleck. 1995. The division abnormally delayed (dally) gene: a putative integral membrane proteoglycan required for cell division patterning during postembryonic development of the nervous system in Drosophila. Development. 121:3687-3702.

49. Pilia, G., R.M. Hughes-Benzie, A. MacKenzie, P. Baybayan, E.Y. Chen, R. Huber, G. Neri, A. Cao, A. Forabosco, and D. Schlessinger. 1996. Mutations in GPC3, a glypican gene, cause the Simpson-Golabi-Behmel overgrowth syndrome. Nat. Genet. 12:241-247.

50. Lindsay, S., M. Ireland, O. O'Brien, J. Clayton-Smith, J.A. Hurst, J. Mann, T. Cole, J. Sampson, S. Slaney, D. Schlesinger, J. Burn, and G. Pilia. 1997. Large scale deletions of the GPC3 gene may account for a minority of cases of Simpson-Golabi-Behmel syndrome. J. Med. Genet. 34:480-483.

51. Carey, D.J., K. Conner, V.K. Asundi, D.J. Omahony, R.C. Stahl, L. Showalter, G. Smith, J. Hartman, and L.I. Rothblum. 1997. cDNA cloning, genomic organization, and in vivo expression of rat $\mathrm{N}$-syndecan. J. Biol. Chem. 272:2873-2879.

52. Schwarz, L.C., T. Inoue, T. Irimura, J.E. Damen, A.H. Greenberg, and J.A. Wright. 1990. Relationships between heparanase activity and increasing metastatic potential of fibroblasts transfected with various oncogenes. Cancer Lett. 51:187-192.

53. Laskov, R., R.I. Michaeli, H. Sharir, E. Yefenof, and I. Vlodavsky. 1991 Production of heparanase by normal and neoplastic murine B-lymphocytes. Int. J. Cancer. 47:92-98.

54. Freeman, C., and C.R. Parish. 1997. A rapid quantitative assay for the detection of mammalian heparanase activity. Biochem. J. 325:229-237.

55. Kosir, M.A., C.C. Quinn, K.L. Zukowski, D.J. Grignon, and S. Ledbetter. 1997. Human prostate carcinoma cells produce extracellular heparanase. $J$. Surg. Res. 67:98-105.

56. Prigent, S.A., and N.R. Lemoine. 1992. The type 1 (EGFR-related) fam ily of growth factor receptors and their ligands. Prog. Growth Factor Res. 4:124.

57. Raab, G., and M. Klagsbrun. 1997. Heparin-binding EGF-like growth factor. Biochim. Biophys. Acta. 1333:F179-F199.

58. Filla, M.S., P. Dam, and A.C. Rapraeger. 1998. The cell surface proteoglycan syndecan-1 mediates fibroblast growth factor-2 binding and activity. J. Cell. Physiol. 174:310-321.

59. De Klerk, D.P. 1984. Glycosaminoglycans of human prostatic cancer. J. Urol. 131:1008-1012.

60. De Klerk, D.P. 1985. The glycosaminoglycans of human bladder cancers of varying grade and stage. J. Urol. 134:978-981.

61. Kovalszky, I., Z. Scharff, and A. Jeney. 1993. Potential markers (enzymes, proteoglycans) for human liver tumors. Acta Biomed. Ateneo Parmense 64:157-163.

62. Nackaerts, K., E. Verbeken, G. Deneffe, B. Vandershueren, M. Demedts, and G. David. 1997. Heparan sulfate proteoglycan expression in human lung-cancer cells. Int. J. Cancer. 74:335-345.

63. Levy, P., A. Munier, S. Baron-Delage, Y. DiGioia, C. Gespach, J. Capeau, and G. Cherqui. 1996. Syndecan-1 alterations during the tumorigenic progress of human colonic Caco-2 cells induced by human Ha-ras or polyoma middle T oncogenes. Br. J. Cancer. 74:421-423.

64. Inki, P., H. Joensuu, R. Gronman, P. Klemi, and M. Jalkanen. 1994. Association between syndecan-1 expression and clinical outcome in squamous cell carcinoma of the head and neck. Br. J. Cancer. 70:319-323.

65. Kloppel, G., and B. Maillet. 1991. Chronic pancreatitis: evolution of the disease. Hepatogastroenterology. 38:408-412.

66. Friess, H., J. Kleeff, and M.W. Büchler. 1997. Growth factors and growth factor receptors in chronic pancreatitis. In Advances in Pancreatic Disease. C.G. Dervenis, editor. Georg Thieme Verlag Stuttgart, New York. 26-32. 